Article

\title{
A Comparative Analysis of the Use of the Concept of Sustainability in the Romanian Top Universities' Strategic Plans
}

\author{
Claudia E. Stoian*(D), Simona Șimon *(D) and Vasile Gherheș (D) \\ Department of Communication and Foreign Languages, Politehnica University of Timișoara, \\ 300006 Timișoara, Romania; vasile.gherhes@upt.ro \\ * Correspondence: claudia.stoian@upt.ro (C.E.S.); simona.simon@upt.ro (S.Ș.)
}

Citation: Stoian, C.E.; Simon, S.; Gherhes, V. A Comparative Analysis of the Use of the Concept of Sustainability in the Romanian Top Universities' Strategic Plans. Sustainability 2021, 13, 10642. https://doi.org/10.3390/su131910642

Academic Editors: Maki Ikegami and Iain Patton

Received: 27 August 2021

Accepted: 23 September 2021

Published: 25 September 2021

Publisher's Note: MDPI stays neutral with regard to jurisdictional claims in published maps and institutional affiliations.

Copyright: (c) 2021 by the authors. Licensee MDPI, Basel, Switzerland. This article is an open access article distributed under the terms and conditions of the Creative Commons Attribution (CC BY) license (https:// creativecommons.org/licenses/by/ $4.0 /)$.

\begin{abstract}
As the effects of climate change on today's society make the headlines across the globe, urging all stakeholders to join forces to act and to create a sustainable world, universities have started engaging in the process of building a sustainable future for the generations to come. The sustainable university has thus emerged, a pro-active and collaborative university that performs in several domains. Since the university's strategic plan is an instance of official and public communication on the future institutional development, its investigation reveals the university's position towards sustainability. This study highlights the explicit use of the concept of sustainability in the strategic plans for 2020-2024 of the twelve Romanian top universities and points to the sustainable domains associated with it. Moreover, to determine the direction towards which the Romanian top universities are heading, in terms of sustainability, the article draws a comparison with previous research conducted on the strategic plans for 2016-2020. The main conclusion reached is that although there is an increasing tendency to use the concept in the latest strategic plans, building sustainable universities in Romania is still a goal to be achieved in the future.
\end{abstract}

Keywords: sustainability; Romanian sustainable universities; sustainable; sustainable development; durable development; university's role and values; strategic plan; sustainability domains; comparative analysis

\section{Introduction}

Higher education institutions have changed in time due to the social, economic and technological progress, so that the role they played in forming educated people able to bring their contribution to the overall development of society has also undergone alterations to fit the needs of the community. Although, at the beginning, universities were perceived as ivory towers, accessible only to the chosen ones and responsible with students' acquisition of general knowledge, little by little, they turned into open and versatile institutions, actively engaged in society through the relationship established with the economic environment, the socially responsible citizens they educate and the society as a whole.

Therefore, while the first universities concentrated on gaining knowledge for its own sake, focusing on acquiring the Christian values, the universities that emerged later focused on gaining knowledge to put it to the service of society, a society that, once the technological progress occurred, gradually turned to scientific truths rather than theological ones [1-13]. As such, particularly the Industrial Revolutions [14,15] determined "a shift from dialectic to didactic pedagogy" [3] (p. 12), from the acquisition of theoretical knowledge to that of practical skills, needed in an industrial society. In addition, although the entire industrialization and, more recently, the digitalization of the society contributed to its development and to the improvement of the living standards, they have affected the environment for centuries [14,16-18]. As a result, warnings about our unresponsible behavior towards the 
natural resources of our planet were issued already in the 19th century and, one century later, even measures started to be taken to raise people's awareness of the dangers represented by the ecological catastrophe foreseen and to determine everyone to act to prevent it $[14,15,18,19]$.

At the moment, because of the "massification, globalization, marketization, and digitalization" [12] (p. 21) of the higher education institutions and of the climate change that affects us all, calling for immediate and effective action, as already stated above, "the millennium-old university structure needs profound and radical rethinking" [20] (p. 1). Thus, the role that the present-day universities play in society as well as the values they foster need to change in order to better answer the problems that today's society is facing. In this context, the sustainable university has appeared.

Since the strategic plans of the universities are official documents setting their development goals, they show the direction towards which the higher education institutions are heading and, as such, they are worth being investigated. The aim of the present article is to highlight the explicit use of the concept of sustainability in the Romanian top universities' strategic plans for 2020-2024 and 2016-2020, respectively. To attain this, a presentation of the emergence of sustainable universities both worldwide and in Romania, pointing to the way in which these implement and advance the concept of sustainability in the community has been done. Then, a quantitative and qualitative analysis has been performed, followed by the comparison and discussion of the research findings. Finally, the research conclusions on the use of the concept of sustainability in the Romanian top universities' strategic plans for the last two terms have been drawn. Thus, although there is an increasing interest in building sustainable universities in Romania, this is a goal to be achieved in the future.

\section{Literature Review}

\subsection{The Emergence of Sustainable Universities and Their Role in Society}

Since 1968, the United Nations Educational, Scientific and Cultural Organization (UNESCO) has been advocating for all stakeholders' engagement in the changes that the entire society should experience in order to ensure its sustainability for future generations, i.e., the economic and environmental viability of the social communities necessary for the survival of humanity [21-23]. As one of the major contributors to the creation and development of our society, universities have lately embarked on this endeavor and embraced a new role, namely, that of building a sustainable world [24-26]. Thus, the sustainable university has appeared $[4,24,26-50]$, a collaborative university that works together with all stakeholders, be they organizations, institutions or individuals, to find effective solutions to the environmental problems and to further sustainable practices within the university and the community in which it operates [24,27,51].

Policy, operations, evaluation and optimization are the key elements that underlie the creation of a sustainable university [27]. The values, that a university fosters, are encapsulated in the documents that describe the university's policy: the university's strategy, its organizational structure, the university's statement, i.e., mission, vision and goals and the university's public relations materials. These documents should explicitly refer to the sustainability strategy of the university [26,27]. The university's operations are in fact, all the activities [27] carried out by the higher education institution in the following domains: (I) quality teaching, (II) research culture, (III) technological capacity building, (IV) accessibility to university education, (V) community engagement, (VI) internationalization and (VII) natural environment [24]. To create a sustainable university, sustainable measures in all these domains should be considered in the university's policy documents. Evaluation is about the quality standards and the quality assessment of the university's operations, while optimization refers to the innovative solutions that are put forth in order to solve the sustainability problems identified during the evaluation process.

Since higher education institutions have "the moral obligation" [51] (p. 8) to contribute to the development of sustainable societies, sustainability at the university level has been approached in various manners. For example, sustainability declarations, charters 
and partnerships among higher education institutions have been signed in order to create common frameworks within which concrete actions are put forth to develop sustainable communities [51]. Eleven of these initiatives (the Talloires Declaration, the Halifax Declaration, the Swansea Declaration, the Kyoto Declaration, the Global Higher Education for Sustainability Partnership, the Copernicus Charter, the Lüneburg Declaration, the Declaration of Barcelona, the Graz Declaration, the Turin Declaration and the Abuja Declaration) have been analyzed by Lozano et al. [51] from two perspectives: (1) the wording complexity of the text, i.e., the number of words and of bullets, providing information on the complexity of the topic development and (2) the university system. In addition to the fact that some declarations, charters and partnerships cover the topic more extensively than others, some "key elements and principles" [51] (pp. 8, 9) have been singled out, namely, the university system which encompasses curricula, research, operations, outreach and assessment and reporting; the collaboration with other universities; the integration of sustainability within the institutional framework, providing "on-campus life experiences; and 'Educate-the-Educators' programmes" [51] (pp. 8, 9). These should be integrated in the university to support, in the long run, the sustainable development of the society.

Considering all this, universities have designed and tested various sustainability models in an effort to meet the needs of the present as well as of the future society [4,24,26-33]. These models describe the measures that have been taken by higher education institutions to contribute to a sustainable world. As such, since universities resort to education and research "to equip their students with knowledge, values and skills" [33] (p. 18), it is these areas that need to be reconsidered from a sustainable perspective. Therefore, sustainability programs for educators have been created in order to prepare the ground for the inclusion, in the academic curriculum, of topics and courses dealing with sustainability issues that are approached multi-, inter- and trans-disciplinarily [31,34-41]. Additionally, universities have tried and found sustainable research-based solutions for their campuses, which are described as best practice in the literature $[31,32,42,43]$. Thus, some of the topics they cover are natural heritage, waste management, water and energy efficiency, equity, poverty, access for disabled people, transportation and commuting solutions, dining services, occupational health and safety, ergonomics and environmentally friendly product procurement. However, higher education institutions in post socialist countries are still in their infant phase in terms of campus sustainability, as emphasized by Dagiliūtè, Liobikiené and Minelgaitè [52]. Finally, higher education institutions have also actively engaged in the community to raise awareness of the concept of sustainability and to foster sustainable practices [45-49]. This is extremely important because the students educated by universities live and, later, work in the community and, as such, in time, they can reshape the entire society on a sustainable basis.

All these actions have been included in the university's policy documents and the results described in reports meant to improve the entire sustainable development of the university and of the community in which this activated [26,31,32,34,44,50,53]. Moreover, in order to identify the sustainable measures taken by universities across the globe, on vision and mission statements, qualitative content analyses have been conducted [53-55], as well as quantitative analyses of the frequency of occurrences of the selected keywords [53]. A similar qualitative and quantitative content analysis has been carried out on the universities' strategic plans since the latter ones mirror the sustainability strategies that the universities intend to develop [50].

\subsection{The Emergence of Sustainable Universities in Romania}

As a member state of the European Union, Romania has also adopted the United Nations' 2020 Agenda for Sustainable Development and 2030 Agenda for Sustainable Development [56], which marked the moment when the Romanian government started to pay more attention to the sustainability issues that need to be tackled not only globally, but also locally. Although, at a national level, Romania strives, not always successfully, to meet the European indicators for achieving the sustainable development goals set by the United 
Nations, in terms of education, the focus is on the primary and secondary education rather than on the tertiary one. Nevertheless, even in these areas, small steps forward have been taken so far, which might be explained by the budget allocated to the Romanian education system which, in the past years, was about $1 \%$ lower than the European average $[57,58]$.

Prada, Apostu and Gogu [59] have performed an analysis of the Romanian "normative and legislative framework, as the main mobilizing factor regarding the implementation of the university sustainability" [59] (p. 270) and of the education offer in terms of bachelor's and master's study programs in the field of sustainability. The study has emphasized that "the sustainable university development in Romania is at the beginning, because there are shortcomings of the legislation in the field of sustainable education or of the internal regulations, and the re-design of the curricula by introducing new disciplines is a difficult activity and bureaucratic, with many managerial, motivational, psychological and other difficulties" [59] (p. 276). Despite the signaled impediments, the technical universities in Romania have timidly introduced courses or topics on sustainable development, both at the bachelor and at the master level, as the content analysis of the education offer of engineering study programs has revealed. Although there is a close link between sustainable development and the field of engineering, as the latter one offers solutions to the former one, it would have been expected to find an overwhelming number of courses and topics focusing on sustainability. Nevertheless, the Romanian technical universities "are making small steps towards becoming sustainable universities" [60] (p. 15), at least from the perspective of a sustainability-centered curriculum.

A solution to the development of sustainable universities in Romania has been proposed by Popescu et al. [61] who have conducted a multicriteria analysis of the counties in which the Romanian universities operate. The research results have shown that the digitalization degree of each county is strongly connected to the number of faculties existing in the region scrutinized. The analysis has also revealed that, in order to foster the development of sustainable universities through sustainable campuses, the digitalized rural areas in Romania might offer very promising solutions.

Another perspective on the Romanian sustainable universities is brought by the students participating in surveys conducted at two of the most important universities in Romania, the University of Bucharest and the Bucharest University of Economic Studies. On the one hand, the students pursuing a degree at the Faculty of Business and Administration of the University of Bucharest have participated in a survey that has shown that "social responsibility activities contribute to the development of sustainable higher education institutions through the active engagement and participation of their students" [62] (p. 447). On the other hand, the students at the Bucharest University of Economic Studies have expressed their opinions on the way in which the "sustainable campus initiatives, teaching staff involvement and curricula" [63] (p. 1) have helped them to develop sustainable behaviors. The sustainability topics approached in class and teachers' involvement in raising students' "awareness of the sustainability issues are crucial to students' sustainable behavior" [63] (p. 1). Unexpectedly, however, students are ready to embrace on-campus optional actions and not compulsory ones [63]. Within the Bucharest University of Economic Studies, research has also been conducted to identify students' perceptions regarding the education for sustainable development received during their university studies, which is, however, considered to be "at an early stage" [64] (p. 346). Moreover, the students at the Bucharest University of Economic Studies as well as the representatives of the Alumni Association of the aforementioned university have been asked to express their opinion on the vectors that contribute to the creation of a sustainable university in the field of business and economy [65]. Their opinions and those given by the academia and management representatives have validated the initial hypothesis, previously postulated by Dabija et al. [66], namely, that "the teaching process/education; research; the ecological behavior around the campus; the principles of social responsibility when dealing with stakeholders" [65] (p. 338) are the most important vectors in building a sustainable university. Additionally, the study has revealed that "a long term, system way of thinking that also includes the sustainable 
orientation of the academic institution, implemented through the strategic management plan and in the current management activity" [65] (p. 341) is imperiously necessary.

This conclusion is supported also by other scholars $[26,27,50]$, who additionally consider that the concept of sustainability should be explicitly employed in all the policy documents of the university in order to ensure the acquisition of the concept. Hence, the justification of the quantitative and qualitative linguistic analysis performed on the strategic plans for 2016-2020 of the Romanian top universities [50], which has aimed to identify the explicit use of the concept of sustainability, i.e., all its linguistic embodiments: sustainability, sustainable development (durable development) and sustainable, in order to infer the stance taken by these universities towards sustainability by describing the linguistic context in which they appear and by identifying the domains in which a sustainable university should perform [24], namely, (I) quality teaching, (II) research culture, (III) technological capacity building, (IV) accessibility to university education, (V) community engagement, (VI) internationalization and (VII) natural environment. One of the major concerns revealed by the analysis has referred to the availability of financial resources that may be used to find and implement customed sustainable solutions [50]. Therefore, since no sustainable measures can be taken in the domains listed above without proper funding, it is imperiously necessary, in our opinion, to add the eighth domain, namely, (VIII) finance, in which a sustainable university should perform.

\section{Research Methodology}

The present study analyses the explicit use of the concept of sustainability in the strategic plans for 2020-2024 of the twelve Romanian top universities and compares the results with those obtained from the analysis of the strategic plans for 2016-2020 in order to identify the direction in which the universities' official and public communication on sustainability is moving nowadays. For this purpose, the following research question has been formulated: How is the concept of sustainability used in the Romanian top universities' strategic plans for 2020-2024 in comparison with those for 2016-2020? In order to answer this question, four research objectives have been set:

$\mathrm{RO}_{1}$ : to identify words and phrases that stand for the concept of sustainability in Romanian, i.e., the words sustainability and sustainable as well as the phrases sustainable development and durable development-these two phrases are synonymous in Romanian -, in the universities' strategic plans for 2020-2024,

$\mathrm{RO}_{2}$ : to quantify their frequency of use,

$\mathrm{RO}_{3}$ : to determine the sustainable university domain with which they are associated, $\mathrm{RO}_{4}$ : to draw a comparison between the analysis of the Romanian top universities' strategic plans for 2020-2024 and 2016-2020 [50], respectively.

In order to achieve these objectives, several research stages have been gone through. First, the corpus, comprising the Romanian top universities' strategic plans for 2020-2024, has been compiled. Second, a quantitative analysis has been carried out to single out the frequency of use of the words sustainability and sustainable as well as the phrases sustainable development and durable development in Romanian. Third, a qualitative analysis of the linguistic context, where these words and phrases appear, has been conducted in order to highlight the domain in which the university intends to take sustainable measures. Both for the quantitative and the qualitative analysis, reference to the results obtained from the analysis of the Romanian top universities' strategic plans for 2016-2020 [50] has been made. Fourth, the data gathered from the comparative analysis has been critically interpreted to find the direction towards which the sustainability strategy of the university is heading.

\subsection{Establishing the Corpus}

Although interest in classifying higher education institutions has existed across the globe for more than a century $[3,67]$, in Romania, the first classification of universities was done in 2011 and it established three classes, which are here enumerated from the most prestigious to the least prestigious one: (1) advanced research- and teaching-oriented 
universities, (2) teaching- and scientific research-oriented universities and teaching- and artistic creation-oriented universities and, finally, (3) teaching-oriented universities [68]. Since it has been ascertained that larger public universities are usually more influential in promoting sustainability in their communities than the smaller ones [69], it has been considered that the most prestigious universities have also a similar effect on the local communities as the larger public ones. Thus, the present study looks at the universities included in the most prestigious class [70], namely, the advanced research- and teachingoriented universities, listed alphabetically below:

- Alexandru Ioan Cuza University of Iași,

- Babeș-Bolyai University,

- Bucharest University of Economic Studies,

- "Carol Davila" University of Medicine and Pharmacy Bucharest,

- "Gheorghe Asachi" Technical University of Iași,

- "Iuliu Hațieganu" University of Medicine and Pharmacy Cluj-Napoca,

- Politehnica University of Bucharest,

- Politehnica University of Timișoara,

- Technical University of Cluj-Napoca,

- University of Agricultural Sciences and Veterinary Medicine Cluj-Napoca,

- University of Bucharest,

- University of Medicine and Pharmacy "Grigore T. Popa" Iași.

The university websites have provided each university's officially accepted name in English as well as the strategic plans for 2020-2024 used to carry out the quantitative and qualitative analyses underlying the present research [71-82].

\subsection{Quantitative Analysis}

The quantitative analysis has aimed at singling out the words sustainability and sustainable as well as the phrases sustainable development and durable development in the Romanian top universities' strategic plans for 2020-2024 in order to determine their frequency of occurrence. Such an analysis highlights relevant information that appears at the discourse surface and that can be used as a starting point for understanding and interpreting the message conveyed [83-88].

Table 1 below indicates the results of the quantitative analysis performed on the corpus of the strategic plans for 2020-2024.

Similar to the previous analysis, not all the universities have used the word sustainability and/or its related forms in their strategic plans, as indicated in Table 1. The University of Bucharest is the one that makes no reference to the concept, while others make little reference to it, such as Alexandru Ioan Cuza University of Iaşi (1), Babeș-Bolyai University (2), the University of Medicine and Pharmacy "Grigore T. Popa" Iași (2), or use it frequently, e.g., Bucharest University of Economic Studies (24). The other universities are situated in between the two extremes, although not exceeding ten occurrences. Some of them even have entire chapters/subchapters dedicated to the concept, such as Bucharest University of Economic Studies, "Carol Davila" University of Medicine and Pharmacy Bucharest and the Technical University of Cluj-Napoca.

Regarding the words used, it appears that there is a certain preference for durable development, followed by sustainability. The former, is preponderantly used by Bucharest University of Economic Studies (22). "Carol Davila" University of Medicine and Pharmacy Bucharest also employs the phrase frequently, while other universities, such as the University of Agricultural Sciences and Veterinary Medicine Cluj-Napoca, "Gheorghe Asachi" Technical University of Iași, "Iuliu Haţieganu" University of Medicine and Pharmacy Cluj-Napoca and Politehnica University of Timişoara, use it rarely or not at all (in the case of the six universities left). The later, in turn, appears in all the plans, except for that of the University of Bucharest, being more frequent in the case of Politehnica University of Bucharest (4). 
Table 1. Frequency summary.

\begin{tabular}{|c|c|c|c|c|c|}
\hline Frequency & Sustainability & Sustainable & $\begin{array}{l}\text { Sustainable } \\
\text { Development }\end{array}$ & $\begin{array}{c}\text { Durable } \\
\text { Development }\end{array}$ & Total \\
\hline Alexandru Ioan Cuza University of Iaşi & 1 & - & - & - & 1 \\
\hline Babeș-Bolyai University & 1 & - & 1 & - & 2 \\
\hline Bucharest University of Economic Studies & 2 & - & - & 22 & 24 \\
\hline $\begin{array}{l}\text { "Carol Davila" University of Medicine } \\
\text { and Pharmacy Bucharest }\end{array}$ & 3 & - & - & 6 & 9 \\
\hline $\begin{array}{c}\text { "Gheorghe Asachi" Technical University } \\
\text { of Iași }\end{array}$ & 3 & - & - & 1 & 4 \\
\hline $\begin{array}{l}\text { "Iuliu Haţieganu" University of Medicine } \\
\text { and Pharmacy Cluj-Napoca }\end{array}$ & 1 & 3 & - & 1 & 5 \\
\hline Politehnica University of Bucharest & 4 & 2 & - & - & 6 \\
\hline Politehnica University of Timişoara & 1 & 1 & - & 1 & 3 \\
\hline Technical University of Cluj-Napoca & 2 & 1 & 4 & - & 7 \\
\hline $\begin{array}{c}\text { University of Agricultural Sciences and } \\
\text { Veterinary Medicine Cluj-Napoca }\end{array}$ & 1 & - & - & 2 & 3 \\
\hline University of Bucharest & - & - & - & - & 0 \\
\hline $\begin{array}{l}\text { University of Medicine and Pharmacy } \\
\text { "Grigore T. Popa" Iași }\end{array}$ & 1 & 1 & - & - & 2 \\
\hline TOTAL & 20 & 8 & 5 & 33 & 66 \\
\hline
\end{tabular}

As for sustainable and sustainable development, these appear rarely comparing to the former discussed. Sustainable is preferred by "Iuliu Haţieganu" University of Medicine and Pharmacy Cluj-Napoca, followed by Politehnica University of Bucharest, Politehnica University of Timişoara, the Technical University of Cluj-Napoca and the University of Medicine and Pharmacy "Grigore T. Popa" Iași. The other universities do not mention it at all. Sustainable development, in turn, is used only by two universities, i.e., Babeș-Bolyai University and the Technical University of Cluj-Napoca.

Compared to the previous results [50], the number of occurrences of the concept analyzed has significantly grown (66 vs. 43). The most important growth is in the case of durable development, which has reached 33 occurrences compared to 14 . As indicated in Figure 1, some universities have kept their interest in the concept of sustainability or have maintained a similar number of instances, such as Babeș-Bolyai University, Politehnica University of Bucharest, others have focused more on the concept, namely, Bucharest University of Economic Studies, "Carol Davila" University of Medicine and Pharmacy Bucharest, "Gheorghe Asachi" Technical University of Iași "Iuliu Haţieganu" University of Medicine and Pharmacy Cluj-Napoca, the Technical University of Cluj-Napoca and the University of Agricultural Sciences and Veterinary Medicine Cluj-Napoca, or have focused less, i.e., Alexandru Ioan Cuza University of Iaşi, Politehnica University of Timişoara, the University of Bucharest and the University of Medicine and Pharmacy "Grigore T. Popa" Iași, than in the past. The most relevant changes have been found in the case of "Iuliu Haţieganu" University of Medicine and Pharmacy Cluj-Napoca, which has started using the concept, Bucharest University of Economic Studies, which has used the concept ten times more and the University of Bucharest, in whose plan the concept does not appear at all. 


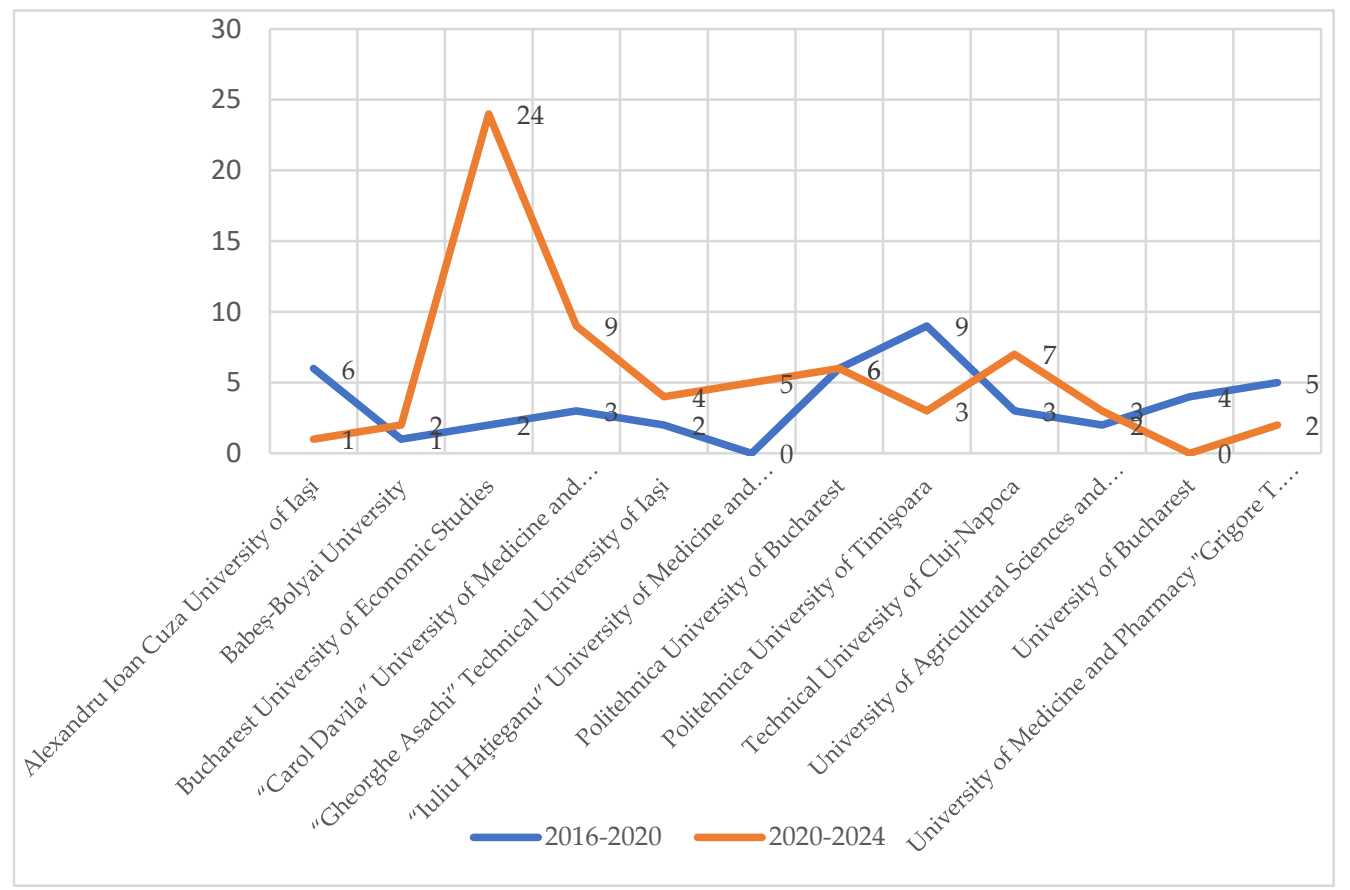

Figure 1. A diachronic comparison of the use of the concept of sustainability.

The preference for the same words has been kept, i.e., durable development and sustainability. The universities preferring that particular words have changed though, Alexandru Ioan Cuza University of Iaşi has been replaced by Politehnica University of Bucharest and Politehnica University of Timişoara by Bucharest University of Economic Studies. Sustainable, instead, is not that frequent as in the previous plans. Some universities have continued to use the term (Politehnica University of Bucharest, Politehnica University of Timişoara and the University of Medicine and Pharmacy "Grigore T. Popa" Iași), some have not included it anymore (Alexandru Ioan Cuza University of Iaşi, Bucharest University of Economic Studies, "Carol Davila" University of Medicine and Pharmacy Bucharest and the University of Agricultural Sciences and Veterinary Medicine Cluj-Napoca), while others have added it to their new strategic plans ("Iuliu Haţieganu" University of Medicine and Pharmacy Cluj-Napoca and the Technical University of Cluj-Napoca). Finally, sustainable development maintains a low occurrence also in the new strategic plans for 2020-2024. It does not appear at all in the plans of the universities where it was previously found, namely, the University of Medicine and Pharmacy "Grigore T. Popa" Iași, Politehnica University of Bucharest and Politehnica University of Timişoara, but it is newly adopted by the Technical University of Cluj-Napoca and Babeș-Bolyai University.

\subsection{Qualitative Analysis}

Since sustainability is one of the current concerns of humanity [89], it should be also dealt with in the Romanian top universities' strategic plans, which "are official projects of the university, designed and written at a certain moment in time by somebody in particular, being, thus, the reflection of a certain society and culture" [50] (p. 5). Hence, the analysis of the linguistic context, in which the words and phrases standing for the concept of sustainability appear in the university's strategic plans, has been conducted to determine the domain with which they are associated and in which a sustainable university should perform. To the seven domains described in the literature [24], we have argued in Section 2.2. The Emergence of Sustainable Universities in Romania of the present article in favor of adding one more essential domain, namely, finance. Therefore, for the analysis presented below, the following eight domains have been considered: (I) quality teaching, (II) research culture, (III) technological capacity building, (IV) accessibility to university education, (V) 
community engagement, (VI) internationalization and (VII) natural environment and (VIII) finance. The explicit use of the concept of sustainability in all its linguistic forms and its association with one of the domains in which a sustainable university must perform "points to the university's preoccupation with developing sustainable practices" [50] (p. 6). The linguistic context in which the words sustainability and sustainable as well as the phrases sustainable development and durable development are employed in the strategic plans for 2020-2024 has been translated into English; the Romanian excerpts are found in Appendix A. Furthermore, to ease the comparison between the strategic plans for the previous and for the current terms, the linguistic context translated into English and extracted from the strategic plans for 2020-2024 is included in tables, along with the one from the strategic plans for 2016-2020. The universities' strategic plans and the research findings are presented observing the alphabetical list of the twelve Romanian top universities given above, in Section 3.1. Establishing the corpus.

\subsubsection{Alexandru Ioan Cuza University of Iaşi}

Table 2 presents the instances in which the keywords searched for appear in the two strategic plans the research team has focused on, namely, those for 2016-2020 [50] and 2020-2024 [71].

Table 2. Comparison of the strategic plans of Alexandru Ioan Cuza University of Iaşi.

\begin{tabular}{|c|c|c|}
\hline Word/Phrase & Strategic Plan 2016-2020 [50] (p. 7) & Strategic Plan 2020-2024 [71] \\
\hline \multirow{4}{*}{ sustainability } & $\begin{array}{l}\text { "Establish an effective institutional dialogue with the } \\
\text { managing authorities and the implementing bodies, both in } \\
\text { the consultation and pre-contracting phase and in the } \\
\text { implementation and sustainability phase (p. 5)" }\end{array}$ & \multirow{4}{*}{$\begin{array}{l}\text { Among the important strategic directions of } \\
\text { the University, we mention ensuring financia } \\
\text { sustainability and legal security of the UAIC } \\
\text { assets. (p. 19) }\end{array}$} \\
\hline & $\begin{array}{l}\text { "The administrative component acts as a support element for } \\
\text { the fulfilment of the functions of education and research, } \\
\text { being also one of the basic components for the sustainability } \\
\text { of the activity (p. 7)" }\end{array}$ & \\
\hline & $\begin{array}{l}\text { "The valorization of the research results in the socio-economic } \\
\text { environment contributes decisively to the sustainability of the } \\
\text { activity, as well as to the insurance of the necessary financing } \\
\text { (p. 15)" }\end{array}$ & \\
\hline & $\begin{array}{l}\text { "ensuring the sustainability of the quality of the educational } \\
\text { and research process - I propose a process of selecting in the } \\
\text { academic body, as tenured or associate teaching staff, of } \\
\text { specialists with national or international recognition as well as } \\
\text { promoting the best graduates of the university and doctoral } \\
\text { students in teaching and scientific research activities (p. 19)" }\end{array}$ & \\
\hline \multirow{2}{*}{ sustainable } & $\begin{array}{l}\text { "The specific objective is to ensure a sustainable management, } \\
\text { through the optimal functioning of the institution and the } \\
\text { development of new investments (p. 7)" }\end{array}$ & \multirow[t]{2}{*}{-} \\
\hline & $\begin{array}{l}\text { "The development of this type of activity can be sustainable } \\
\text { and does not bring additional costs, being able to materialize } \\
\text { in a source of income for the University (p. 10)" }\end{array}$ & \\
\hline $\begin{array}{c}\text { sustainable } \\
\text { development }\end{array}$ & - & - \\
\hline $\begin{array}{c}\text { durable } \\
\text { development }\end{array}$ & - & - \\
\hline
\end{tabular}

Alexandru Ioan Cuza University of Iaşi presents its strategy [71] in a 40 page-long document. Within this, sustainability appears only once, at page 19. The same relation is maintained from the previous strategic plan, namely, sustainability-finance. In this case, it is included at the beginning of the sixth part of the plan, i.e., the administration 
and management of the patrimony for the period 2016-2024. Particularly, it refers to the assets of the university since ensuring their financial sustainability and legal security is an important strategic direction for the managerial board. As this is the only instance of the focused keywords, the references to management, administration, education, research, technological transfer and human resources from the 2016-2020 plan are lost in the 2020-2024 one.

Considering the length of the plan and the occurrences of the concept, the new management strategy does not pay such attention to sustainability as the previous one. The only perspective adopted is the financial one.

\subsubsection{Babeș-Bolyai University}

The comparison between the two strategic plans of Babeș-Bolyai University is presented in Table 3 below.

Table 3. Comparison of the strategic plans of Babes-Bolyai University.

\begin{tabular}{ccc}
\hline Word/Phrase & \multicolumn{1}{c}{ Strategic Plan 2016-2020 [50] (p. 8) } & \multicolumn{1}{c}{ Strategic Plan 2020-2024 [72] } \\
\hline sustainability & $\begin{array}{l}\text { "Increasing UBB incomes and ensuring the } \\
\text { financial sustainability of all structures within } \\
\text { the university (p. 31)" }\end{array}$ & $\begin{array}{l}\text { In the end, the UBB graduate must be able to integrate flexibly } \\
\text { and efficiently in the academic environment and/or in the } \\
\text { labor market, to whose sustainability and also innovative } \\
\text { change he/she can contribute as an active and responsible } \\
\text { citizen, shaping mindsets and visions at the level of the society } \\
\text { in general, not only at that of the economic world. (p. 8) }\end{array}$ \\
\hline $\begin{array}{c}\text { sustainable } \\
\text { development }\end{array}$ & - & $\begin{array}{l}\text { At this level, the university must think in terms of sustainable } \\
\text { development. (p. 20) }\end{array}$ \\
\hline $\begin{array}{c}\text { durable } \\
\text { development }\end{array}$ & - & \\
\hline
\end{tabular}

The strategic plan of Babeș-Bolyai University for the period 2020-2024 [72] maintains a similar length and number of instances of the concept of sustainability as the previous plan analyzed [50]. It has 32 pages and two instances of the concept. The first time, sustainability appears at page 8 in relation to community engagement. One of the main objectives of the university is education. As such, it aims to train active and responsible citizens. Within this perspective, the graduate from UBB (the Romanian acronym for Universitatea Babes-Bolyai (Babeș-Bolyai University)) must be able to integrate in the labor market and contribute to its sustainability.

Another objective of the university is to have a relationship with society as a main creator of social wellbeing. A possible strategic action to reach this objective is by taking part at the construction of the advantages of Cluj-Napoca (the city where the university is located) at regional level, of Transylvania (the region where the university is located) at national level and of Romania at international level. This can be done by developing spin-offs and programs such as UBB Goes Green. In the section dedicated to the mentioned program, sustainability appears again as sustainable development. In this case, it refers to natural environment and it states the terms within which the university must think.

All in all, Babes-Bolyai University maintains the same interest in the concept of sustainability as in the past. The approach has, though, changed from financial aspects to community engagement and natural environment.

\subsubsection{Bucharest University of Economic Studies}

Table 4 presents the instances in which the keywords sustainability, sustainable, sustainable development and durable development appear in the two strategic plans of Bucharest University of Economic Studies. 
Table 4. Comparison of the strategic plans of Bucharest University of Economic Studies.

\begin{tabular}{|c|c|c|}
\hline Word/Phrase & Strategic Plan 2016-2020 [50] (p. 8) & Strategic Plan 2020-2024 [73] \\
\hline \multirow[t]{2}{*}{ sustainability } & - & $\begin{array}{l}\text { Ensuring our university's financial sustainability and the } \\
\text { improvement of funding capacity for the period 2020-2024 } \\
\text { will be achieved through the following actions: (p. 45) }\end{array}$ \\
\hline & & $\begin{array}{l}\text { Creating a University Sustainability Code and an "ASE for } \\
\text { Durable Development" booklet to be distributed } \\
\text { electronically, through the personal webpage of the academic } \\
\text { community members, to raise awareness of the application of } \\
\text { ASE's green policies. (p. 55) }\end{array}$ \\
\hline \multirow[t]{2}{*}{ sustainable } & $\begin{array}{l}\text { "Achieving new viable and sustainable } \\
\text { partnerships with foreign universities and } \\
\text { European institutions (p. 18)" }\end{array}$ & - \\
\hline & $\begin{array}{l}\text { "Concluding sustainable partnerships in } \\
\text { medium and long term with the business } \\
\text { environment and with specialized state } \\
\text { institutions in the country and abroad (p. 21)" }\end{array}$ & \\
\hline $\begin{array}{c}\text { sustainable } \\
\text { development }\end{array}$ & - & - \\
\hline \multirow[t]{9}{*}{$\begin{array}{c}\text { durable } \\
\text { development }\end{array}$} & \multirow[t]{9}{*}{-} & $\begin{array}{l}\text { In this regard, universities are called to become more involved } \\
\text { in Romania's process of durable development by continuing } \\
\text { to prepare the best specialists for the labor market, creating } \\
\text { and disseminating knowledge to meet the demands of a } \\
\text { global economy, particularly complex and dynamic, } \\
\text { characterized by strong competition, but also by being } \\
\text { involved in identifying the problems faced by the Romanian, } \\
\text { the European and the global economy and formulating } \\
\text { science-based solutions to solve them. (p. } 4 \text { ) }\end{array}$ \\
\hline & & Durable development and social responsibility. (p. 10) \\
\hline & & $\begin{array}{l}\text { Promoting a culture of quality, critical thinking and } \\
\text { innovation among students, based on everybody's } \\
\text { responsibility, in order to ensure durable development of the } \\
\text { Romanian economy. (p. 13) }\end{array}$ \\
\hline & & $\begin{array}{l}\text { ASE's continuing the organization of the Forum for Durable } \\
\text { Development and Entrepreneurship and involving all the } \\
\text { faculties in this initiative, with the purpose of bringing the } \\
\text { academic and research environment, the private economic } \\
\text { sector and representatives of the public administration to the } \\
\text { debate table. (p. 40) }\end{array}$ \\
\hline & & Durable development and social responsibility (p. 54) \\
\hline & & $\begin{array}{l}\text { The ambitious Agenda } 2030 \text { proposed by the United Nations } \\
\text { at the end of } 2015 \text { represents a universal global action } \\
\text { program in the field of durable development. (p. 54) }\end{array}$ \\
\hline & & $\begin{array}{l}\text { From the multiple United Nations Durable Development } \\
\text { Goals, the Bucharest University of Economic Studies aims to } \\
\text { achieve as many as possible. (p. } 54 \text { ) }\end{array}$ \\
\hline & & $\begin{array}{l}\text { In order to achieve the goals that aim at durable development, } \\
\text { for the period 2020-2024, the university can take the following } \\
\text { actions: (p. 54) }\end{array}$ \\
\hline & & $\begin{array}{l}\text { The adoption, at the university level, of "ASE for Durable } \\
\text { Development" (ASE-DD) in order to include and improve } \\
\text { ASE's ranking in the international ranking of the domain, but } \\
\text { also to involve our university in the international movement } \\
\text { for durable development. (p. } 54 \text { ) }\end{array}$ \\
\hline
\end{tabular}


Table 4. Cont.

Word/Phrase Strategic Plan 2016-2020 [50] (p. 8) Strategic Plan 2020-2024 [73]

Posting on the DMCI website, http:/ / dmci.ase.ro/ (accessed on 17 June 2021), scientific and research activities for durable development. (p. 54)

Founding an Office for Durable Development and Social Responsibility to facilitate and support the implementation of the durable development policy in the university and the inclusion of students with diverse learning needs in the university life. (p. 54)

Creating a University Sustainability Code and an "ASE for Durable Development" booklet to be distributed electronically, through the personal webpage of the academic community members, to raise awareness of the application of ASE's green policies. (p. 55)

Continuing the organization of the Forum for Durable Development and Entrepreneurship, which also aims to share the best practices in achieving the UN Durable Development Goals. (p. 55)

Involving students in durable development activities by organizing workshops or other specific student activities. (p. 55)

Promoting a policy of rational use of resources in order to reduce the anthropogenic impact on the environment, including through the implementation of an institution-wide resource efficiency project (encouraging durable development). (p. 55)

Offering awards and scholarships for students' extracurricular, volunteering activities as well as for student scientific research even on durable development topics. (p. 57)

For the period 2020-2021, we aim to maintain the number of the teaching staff at around 800 and to increase the number of scientific researchers, aiming to ensure a structure based on teaching positions that contributes to the durable development of our university. (p. 62)

2030 Agenda for Durable Development (p. 67)

Romania's Durable Development Strategy 2030 (p. 67)

The plan of Bucharest University of Economic Studies for 2020-2024 [73] is quite long, i.e., 69 pages and the keywords focused on appear frequently. The actual word sustainability appears only twice in the second part of the document. The first instance is related to the domain of finance and refers to one of the university's directions in order to achieve the important objective of improving the funding capacity for the modernization and development of the university's infrastructure, namely, ensuring the university's financial sustainability and the improvement of funding capacity for the period 2020-2024. The second time, the domain changes to natural environment and refers to the creation of a university sustainability code and booklet focusing on the university's durable development in order to raise awareness of the application of Bucharest University of Economic Studies' green policies.

Durable development, instead, is very frequent (more than 20 times). It appears for the first time at the beginning, on page 4 , in the first section of the plan dedicated to the university's vision, mission and values. As important actors in the educational process, universities should get more involved in Romania's durable development by training professionals, creating and disseminating knowledge, as well as getting involved 
in identifying problems and finding solutions for the Romanian, European and global economy. In the same framework of community engagement, the university proposes durable development, together with, social responsibility as one of its action directions in order to accomplish its strategic objectives for 2020-2030. Apart from community engagement, durable development is linked also to quality teaching and economy, the idea of training students to contribute to Romanian economy being repeated.

The keyword is most highly used towards the end of the document, mainly in relation to community engagement. ASE (the Romanian acronym for Academia de Științe Economice din București (Bucharest University of Economic Studies)) will continue to organize the Forum for Durable Development and Entrepreneurship to ensure a very good relationship with the socio-economic environment. The managerial plan even has a chapter dedicated to durable development and social responsibility, in which the concept refers to the ambitious Agenda 2030 proposed by the United Nations at the end of 2015 that stands as a global action program and the actions the university plans to take in that direction. It mentions adopting, at the university level, the booklet "ASE for Durable Development" and disseminating it to raise awareness, posting scientific and research activities in the area, founding an office for this goal, continuing the organization of the Forum for Durable Development and Entrepreneurship, involving students in the issue and rewarding them, as well as promoting a policy of rational use of resources. The domains envisaged are, as can be noticed, community engagement, research culture, accessibility to university education and natural environment.

Moreover, durable development is linked also to the resources necessary to implement the managerial program, particularly to human resources. In order to ensure the development of the university, the managerial team will maintain the number of staff and increase that of scientific researchers. In this case, the concept refers to the domains of quality teaching and research culture. The last two times the concept appears is in two titles of the bibliography consulted to write the plan.

To summarize, the new managerial team has changed totally the perspective on sustainability. The concept is ten times more used than in the previous plan. The focus has also shifted from internationalization and technological capacity building to mainly community engagement, followed by research culture, natural environment, finance, research culture and accessibility to university education. The relation between sustainability and quality teaching has been kept. All in all, the strategic plan is aligned to the university's interest in sustainability, which has also been indicated by the studies carried out and discussed in the literature review [63-66].

\subsection{4. "Carol Davila" University of Medicine and Pharmacy Bucharest}

Table 5 below indicates the instances of the concept of sustainability in the two plans compared.

The plan of "Carol Davila" University of Medicine and Pharmacy Bucharest [74] is double in length than the previous one. In addition, the instances of the concept of sustainability are more often. Sustainability is used together with durable development from the beginning of the plan, namely, in the foreword, identifying the spirit within which the university must exist. Then, the word appears in relation to the financial situation of the university and its human capital. The rector aims to support and stimulate the staff's work and to increase the university's incomes to ensure sustainability. This relation between sustainability and finance is developed throughout an entire subchapter within the framework of providing an efficient management. As can be seen, the domains linked to the concept are quality teaching, research culture, internationalization, community engagement and finance. 
Table 5. Comparison of the strategic plans of "Carol Davila" University of Medicine and Pharmacy Bucharest.

\begin{tabular}{|c|c|c|}
\hline Word/Phrase & Strategic Plan 2016-2020 [50] (p. 8) & Strategic Plan 2020-2024 [74] \\
\hline \multirow[t]{3}{*}{ sustainability } & \multirow[t]{3}{*}{-} & $\begin{array}{l}\text { Our university must be positioned, from the perspective of } \\
\text { institutional philosophy, in relation to performance and, from } \\
\text { the point of view of its relationship with competitiveness, in } \\
\text { the spirit of sustainability and durable development } \\
\text { principles. (p. 4) }\end{array}$ \\
\hline & & $\begin{array}{l}\text { All this will be linked with activities that aim at increasing the } \\
\text { university's incomes to ensure sustainability, with a view to } \\
\text { the possibility of granting financial incentives based on } \\
\text { qualitative criteria and the construction of a methodology for } \\
\text { awarding merit bonuses. (p. 14) }\end{array}$ \\
\hline & & $\begin{array}{l}\text { VIII.1. Improving the University's funding capacity and } \\
\text { ensuring sustainability (p. 56) }\end{array}$ \\
\hline \multirow[t]{2}{*}{ sustainable } & $\begin{array}{l}\text { "Sustainable contribution of the university to } \\
\text { durable development and to the achievement } \\
\text { of the highest standard of health in Romania, } \\
\text { in the EU and in the world (p. 11)" }\end{array}$ & \multirow[t]{2}{*}{-} \\
\hline & $\begin{array}{l}\text { "Identification of feasible and sustainable } \\
\text { alternatives for the transition from the current } \\
\text { state to the desirable one (p. 16)" }\end{array}$ & \\
\hline $\begin{array}{l}\text { sustainable } \\
\text { development }\end{array}$ & - & - \\
\hline \multirow[t]{6}{*}{$\begin{array}{c}\text { durable } \\
\text { development }\end{array}$} & \multirow[t]{6}{*}{$\begin{array}{l}\text { "Sustainable contribution of the university to } \\
\text { durable development and to the achievement } \\
\text { of the highest standard of health in Romania, } \\
\text { in the EU and in the world (p. 11)" }\end{array}$} & $\begin{array}{l}\text { Our university must be positioned, from the perspective of } \\
\text { institutional philosophy, in relation to performance and, from } \\
\text { the point of view of its relationship with competitiveness, in } \\
\text { the spirit of sustainability and durable development } \\
\text { principles. (p. 4) }\end{array}$ \\
\hline & & $\begin{array}{l}\text { The vision for the medium and long-term development of our } \\
\text { university is centered, in my view, on a strongly } \\
\text { internationalized institution, anchored in performance and } \\
\text { competitiveness, carrying out a student-centered teaching } \\
\text { process and research activity aligned with the European } \\
\text { Agenda } 2030 \text { for Durable Development. (p. } 4 \text { ) }\end{array}$ \\
\hline & & $\begin{array}{l}\text { By providing scientific evidence, UMFCD participates in } \\
\text { consolidating public policies focused on durable development } \\
\text { and health improvement. (p. 22) }\end{array}$ \\
\hline & & Digitalization-a tool for durable development. (p. 29) \\
\hline & & VII. Digitalization A tool for durable development (p. 54) \\
\hline & & $\begin{array}{l}\text { Identifying funding opportunities in the Competitiveness } \\
\text { Operational Program and in the next EU funding cycle - } \\
\text { Agenda } 2030 \text { for durable development, for digital solutions at } \\
\text { UMFCD. (p. 54) }\end{array}$ \\
\hline
\end{tabular}

The phrase durable development, in turn, appears more frequently and always in relation to digitalization, on the one hand, as one of its instruments within the university's strategic directions in the international, national and institutional contexts, which is further discussed in an entire chapter and to the 2030 European Agenda for Durable Development, on the other, as the research activity should be aligned to the agenda. Through research, the university engages with the community and participates in consolidating public policies focused on durable development and health improvement. The agenda needs to be considered also as a source of European funding for digital solutions at the university level. All in all, the domains within which the concept operates are various, i.e., 
mainly community engagement, research culture and finance, followed by quality teaching, internationalization and technological capacity building.

This time, "Carol Davila" University of Medicine and Pharmacy Bucharest has paid more attention to the concept of sustainability than before. The concept is related to efficient management, digitalization and the actions needed to align to the European Agenda, to which entire chapters/subchapters are dedicated, reaching more aspects than before. Apart from community engagement and quality teaching, which are kept from the previous plan, the other domains (research culture, finance, internationalization and technological capacity building) have been added to the plan, enlarging the university's perspective on sustainability.

\subsection{5. "Gheorghe Asachi" Technical University of Iași}

Table 6 presents the findings of the analyses regarding "Gheorghe Asachi" Technical University of Iași.

Table 6. Comparison of the strategic plans of "Gheorghe Asachi" Technical University of Iași.

\begin{tabular}{ll}
\hline Word/Phrase & \multicolumn{1}{c}{ Strategic Plan 2016-2020 [50] (p. 8) } \\
\hline sustainability & $\begin{array}{l}\text { "Developing a financial discipline of the } \\
\text { institution, by clearly highlighting the } \\
\text { incoming and outgoing flows on university } \\
\text { cost centers, in order to maintain its financial } \\
\text { sustainability (p. 9)" }\end{array}$
\end{tabular}

\section{Strategic Plan 2020-2024 [75]}

Creating training flows, systematizing and certifying them to monetize the activities of the digital transformation support centre to ensure its sustainability; (p. 66)

Systematization and operationalization of smart services offered to beneficiaries, development of exploitation strategies to ensure the sustainability, continuity and scalability of the infrastructure; (p. 67)

Ensuring financial sustainability through overheads commensurate with the resources used-repairs, electricity and other utilities. (p. 67)

\begin{tabular}{cl}
\hline sustainable & - \\
\hline $\begin{array}{c}\text { sustainable } \\
\text { development }\end{array}$ & - \\
\hline $\begin{array}{c}\text { durable } \\
\text { development }\end{array}$ & $\begin{array}{l}\text { "to carry out the activity of scientific research, } \\
\text { development, innovation and technological } \\
\text { transfer, to valorize and disseminate their } \\
\text { results, with the role of inseparable } \\
\text { components from the instructional-formative } \\
\text { process, in order to contribute to technological, } \\
\text { economic and socio-cultural progress, in the } \\
\text { sense of durable development and evolution } \\
\text { towards the society of knowledge (p. 17)" }\end{array}$ \\
&
\end{tabular}

The present plan of the university [75] is longer than the previous one, i.e., 99 pages compared to 67. The concept of sustainability is not more frequent than in the past, considering the length of the document. Now, the concept appears four times, while, in the past, it appeared twice. In the 2020-2024 plan, "Gheorghe Asachi" Technical University of Iași relates the concept specially to finance and community engagement, in the same light as the previous plan. Within these domains, sustainability refers, however, to other aspects than in the 2016-2020 plan, namely, technical assistance and digital transformation and infrastructure in the North-East Developmental Region. The university aims to ensure their sustainability. The idea of financial sustainability is maintained. As for durable development, this remains among the objectives and strategies regarding the research and innovation within the university, being related to the domains of quality teaching, research culture and community engagement. 
To summarize, the university is positioned more or less in the same relation towards the concept. The perspective has become more general and updated, attention being paid to regional development and digitalization.

\subsection{6. "Iuliu Haţieganu" University of Medicine and Pharmacy Cluj-Napoca}

Table 7 below indicates the instance in which the concept of sustainability appears in the strategic plan of "Iuliu Haţieganu" University of Medicine and Pharmacy Cluj-Napoca.

Table 7. Comparison of the strategic plans of "Iuliu Haţieganu" University of Medicine and Pharmacy Cluj-Napoca.

\begin{tabular}{lll}
\hline Word/Phrase & Strategic Plan 2016-2020 & \multicolumn{1}{c}{ Strategic Plan 2020-2024 [76] } \\
\hline sustainability - & $\begin{array}{l}\text { The creation of an administrative facility at the university level to } \\
\text { support scientific activity (in the Research-Development-Innovation } \\
\text { Department), supporting research activity by offering services to } \\
\text { members of the academic community, involving administrative and } \\
\text { economic staff, allowing the provision of research services contributing } \\
\text { to the sustainability of research centers, e.g., statistical data processing, } \\
\text { consultancy on writing scientific articles, consultancy in medical English, } \\
\text { regular information on current funding programmed, proposal and } \\
\text { management of projects, production of scientific impact articles, } \\
\text { scientometric analysis. (p. 20) }\end{array}$ \\
\hline
\end{tabular}

sustainable

sustainable

development

durable

development
The research coordinated with a vision of integration and internationalization, sustainable through projects, must be the priority of our activity as an advanced research university. (p. 13)

Reaching out to the private sector to increase funding for applied and sustainable research from non-public sources. (p. 20)

Foreign students are a major component of university openness as well as an important source of income for the university, the tuition fee education being financially sustainable in the case of foreign language study programs, where the fee is 6000 Euro. (p. 40)

The 17 Durable Development Goals (SDGs) of the National Strategy for 2030 overlap to a large extent with increasing the capacity to attract funding for research in health-related areas. (p. 16)

The "Iuliu Haţieganu" University of Medicine and Pharmacy Cluj-Napoca is the university that has carried out the most important and visible positive change. In the 2016-2020 plan, the concept of sustainability did not appear at all, while in the 2020-2024 [76], it appears five times in different forms throughout a longer document, 45 pages compared to 7 . As such, the concept is related mainly to research and finance. Within the strategic objective of scientific research, the university aims to create an administrative facility at the university level to support scientific activity by offering services to members of the academic community, involving administrative and economic staff, allowing the provision of research services contributing to the sustainability of research centers. As sustainable research could be funded also from non-public sources, the university aims to reach out to the private sector. The link between sustainability and finance is kept also in the description of another objective apart from scientific research, namely, organizational management. In relation to financial resources, fee-based education is presented as sustainable due to the high amount of the tuition fee coming from foreign students. As for durable development, this refers to the 17 goals of the National Strategy for 2030 that overlap with increasing the capacity to attract funding for research in health-related areas.

All in all, the concept of sustainability in the strategic plan of "Iuliu Haţieganu" University of Medicine and Pharmacy Cluj-Napoca makes references mainly to the domains of research culture and finance, followed by community engagement and internationalization. 


\subsubsection{Politehnica University of Bucharest}

Table 8 compares the use of the concept of sustainability in the two plans considered.

Table 8. Comparison of the strategic plans of Politehnica University of Bucharest.

\begin{tabular}{ll}
\hline Word/Phrase & \multicolumn{1}{c}{ Strategic Plan 2016-2020 [50] (p. 8) } \\
\hline sustainability & $\begin{array}{l}\text { "Furthering the values of justice, ethics, } \\
\text { academic freedom, tolerance, participatory } \\
\text { democracy, equal opportunities and } \\
\text { sustainability (p. 19)" }\end{array}$ \\
\cline { 2 - 2 } & "Based on these realities, the \\
& $\begin{array}{l}\text { economic-financial management will have to } \\
\text { continue to consider ensuring the financial } \\
\text { sustainability of the university in all the } \\
\text { components of its functioning, in the medium } \\
\text { and long term (p. 53)" }\end{array}$
\end{tabular}

Strategic Plan 2020-2024 [77]

Building a solid foundation of interdisciplinary skills, sustainability and entrepreneurial thinking through master's programs. (p. 10) sustainability (p. 19)"

"Based on these realities, the continue to consider ensuring the financial stainability of the university in all the and long term (p. 53)"
UPB, along with other universities, must take the lead within national initiatives that aim to expand the nomenclature of posts for ancillary staff with posts that support recent advances, such as data stewards who advise researchers in the management of their (open) research data, metadata curators or curators for the sustainability management of research infrastructures (p. 17)

Ensuring the quality of the working environment and the sustainability of the academic community is a daily concern for the well-functioning of an academic institution. (p. 20)

Writing and creating a sustainability plan for the UPB Campus that follows the modern development tendencies for at least a medium time horizon. (p. 21)

sustainable "New possibilities for sustainable integration of biodiesel production (p. 13)"
Establishing at UPB level a regional, national and international proactive agenda for the development of large-scale, medium and long-term sustainable projects that develops partnerships between public and private organizations and institutions that will achieve links with the research and innovation agenda of collaborating partners from academia, society and industry. (p. 14)

It will be raised the awareness of a sustainable UPB community. (p. 18)

\begin{tabular}{|c|c|c|}
\hline $\begin{array}{c}\text { sustainable } \\
\text { development }\end{array}$ & $\begin{array}{l}\text { "We have perpetually tried to find solutions for } \\
\text { the technological, economic, social challenges } \\
\text { or for those of sustainable development of the } \\
\text { environment in which we operate (p. } 4)^{\prime}\end{array}$ & - \\
\hline \multirow[t]{2}{*}{$\begin{array}{c}\text { durable } \\
\text { development }\end{array}$} & $\begin{array}{l}\text { "There is also the thesis that social } \\
\text { responsibility of universities "contributes to } \\
\text { durable development, including the health and } \\
\text { wellbeing of society, recognizes the } \\
\text { expectations of stakeholders, respects the } \\
\text { international law and rules of conduct and } \\
\text { complies with the relevant rules of } \\
\text { transparency and public accountability" } \\
\text { (Martin, 2013) (p. 16)" }\end{array}$ & - \\
\hline & $\begin{array}{l}\text { "A future concern is the greater involvement of } \\
\text { students in research activities and projects, } \\
\text { wishing to stimulate them, in order to discover } \\
\text { and create knowledge, to contribute to the } \\
\text { achievement of innovations and technological } \\
\text { adaptations in specific fields, in the context of } \\
\text { durable development (p. } 40)^{\prime \prime}\end{array}$ & \\
\hline
\end{tabular}

The Politehnica University of Bucharest seems to pay more attention to the concept of sustainability in the new plan [77]. Even if it has the same number of occurrences, the document is shorter than the previous plan. It is mainly related to the domains of community engagement, quality teaching and research culture. The first two domains 
are kept from the previous plan, quality teaching is new, while the domains of natural environment and technological capacity building have disappeared.

One of the actions carried out by the university is to prepare students so that they contribute to the solving of the society's challenges. As such, Politehnica University of Bucharest aims to provide professional teaching by building a solid foundation of interdisciplinary skills, sustainability and entrepreneurial thinking through master's programs and by ensuring the quality of the working environment and the sustainability of the academic community. At the same time, these actions raise the contribution UPB (the Romanian acronym for Universitatea Politehnica Bucuresti (Politehnica University of Bucharest)) brings to the community, apart from modernizing the campus, creating positions for ancillary staff, such as curators for the sustainability management of research infrastructures and establishing an agenda for the development of large-scale, medium and long-term sustainable projects that develop partnerships between public and private organizations and institutions. The issues mentioned also show a high interest in the research culture and technological capacity building. Even if none of the phrases sustainable/durable development appears in the document, the university has as a stated purpose to raise the awareness of a sustainable UPB community.

To summarize, the concept of sustainability remains important for the new management team of Politehnica University of Bucharest. The interest is to provide quality in teaching and research within a sustainable university community and contribute, thus, to the general wellbeing.

\subsubsection{Politehnica University of Timişoara}

Table 9 focuses on Politehnica University of Timişoara and presents a comparison between the two plans in their instances of the concept analyzed.

The strategic plan of Politehnica University of Timişoara for 2021-2024 [78] has approximately the same length as the one for the period 2016-2020. The frequency of the concept of sustainability is though much lower. If in the previous plan it appeared nine times, now it appears only three times. In the introductory pages, in the last paragraph, meant to summarize the purpose of UPT (the Romanian acronym for Universitatea Politehnica of Timissoara (Politehnica University of Timissoara)) in the coming years, the idea of sustainability appears twice. Going from particular to general, the institutional and regional development leads to the sustainable development of Romania and to the achievement of the sustainability objectives established by the 2030 Agenda of the United Nations and assumed by the European Union. This idea is kept from the previous plan, namely, the fact that Politehnica University of Timişoara wants to be part of sustainable development partnerships, being preoccupied with the development of the society and the collaboration with others. It becomes an objective, not only at an institutional level, but also at a regional one. The 2030 Agenda is brought as new information into the topic, shifting the focus from 2025 to 2030. In addition, the level has gone from regional to European, trying to align with the sustainability objectives of the Union.

The adjective sustainable appears towards the end of the document in relation to the projects of interest for the community in which Politehnica University of Timişoara can participate. These partnerships are included in the direction of the regional socio-economic environment provided in the last strategic axis of UPT for the period 2021-2024, namely, Entrepreneurship and the relationship with the socio-economic environment. Regional commitment.

Taking everything into account, sustainable development, as such, is no longer among the strategic development axes of Politehnica University of Timişoara, but it is included in the entrepreneurial axis. In addition, it no longer appears in connection with human resources or infrastructure as in the previous plan. However, it remains a desideratum of the university and a possibility of development and alignment with European policies. The little attention paid to the concept of sustainability focuses mainly on community engagement and finance. 
Table 9. Comparison of the strategic plans of Politehnica University of Timişoara.

\begin{tabular}{|c|c|c|}
\hline Word/Phrase & Strategic Plan 2016-2020 [50] (p. 9) & Strategic Plan 2020-2024 [78] \\
\hline sustainability & $\begin{array}{l}\text { "Furthering of the concept of sustainability at } \\
\text { the university campus level and at the other } \\
\text { objectives of UPT through measures that take } \\
\text { into account (p. 20)" }\end{array}$ & $\begin{array}{l}\text { Thus, UPT can contribute not only to its institutional } \\
\text { development and to enhancing the competitiveness of the } \\
\text { West Region, but also to Romania's durable development and } \\
\text { to the achievement of the sustainability objectives set by } \\
\text { United Nations } 2030 \text { Agenda and assumed by the European } \\
\text { Union. (p. 9) }\end{array}$ \\
\hline sustainable & $\begin{array}{l}\text { "Initiatives in this field aim to implement a } \\
\text { sustainable strategy in the long term to increase } \\
\text { the performance of human capital (p. 18)" }\end{array}$ & $\begin{array}{l}\text { The university's participation in partnerships with local or } \\
\text { regional authorities to attract state or European funds for the } \\
\text { development of sustainable projects of interest for the } \\
\text { community; (p. 38) }\end{array}$ \\
\hline $\begin{array}{l}\text { sustainable } \\
\text { development }\end{array}$ & $\begin{array}{l}\text { "continuation and intensification of the } \\
\text { partnerships with the local administration in } \\
\text { the promotion of projects of public interest and } \\
\text { sustainable development (p. } 21 \text { )" }\end{array}$ & - \\
\hline \multirow[t]{6}{*}{$\begin{array}{c}\text { durable } \\
\text { development }\end{array}$} & $\begin{array}{l}\text { "Axis V: Infrastructure and durable } \\
\text { development (p. 10)" }\end{array}$ & \multirow{6}{*}{$\begin{array}{l}\text { Thus, UPT can contribute not only to its institutional } \\
\text { development and to enhancing the competitiveness of the } \\
\text { West Region, but also to Romania's durable development and } \\
\text { to the achievement of the sustainability objectives set by } \\
\text { United Nations } 2030 \text { Agenda and assumed by the European } \\
\text { Union. (p. 9) }\end{array}$} \\
\hline & $\begin{array}{l}\text { "At the same time, they also include the } \\
\text { directions on which the carrying out of the } \\
\text { activities related to the mission, namely the } \\
\text { financial dimension and human resources, } \\
\text { depends, which are in turn dependent on } \\
\text { infrastructure and the policies regarding } \\
\text { durable development, computerization (p. 11)" }\end{array}$ & \\
\hline & $\begin{array}{l}\text { "Objectives and support activities regarding } \\
\text { the infrastructure and durable development } \\
\text { (p. 19)" }\end{array}$ & \\
\hline & $\begin{array}{l}\text { "Promotion of cluster type regional structures, } \\
\text { mainly in the field of durable development } \\
\text { (p. 32)" }\end{array}$ & \\
\hline & $\begin{array}{l}\text { "The development of a management strategy } \\
\text { in the following years, so that the year } 2025 \\
\text { (considered a crucial year by the deciders in } \\
\text { the field of education) UPT presents an } \\
\text { efficient leadership, based on the flexible } \\
\text { combination between a professional } \\
\text { management specific to an economic operator } \\
\text { in an aggressive competitive system (which is } \\
\text { able to evaluate the present situation, to } \\
\text { elaborate strategies and action plans that can } \\
\text { be implemented, monitored to ensure durable } \\
\text { institutional development) (p. } 34 \text { )" }\end{array}$ & \\
\hline & $\begin{array}{l}\text { "The increase of public and social } \\
\text { responsibility by intensifying the active } \\
\text { dialogue with the extra-university } \\
\text { environment, by involving the members of the } \\
\text { university community in the elaboration and } \\
\text { implementation of public, social policies (e.g. } \\
\text { for the protection of the environment, } \\
\text { opportunities and equal access, durable } \\
\text { development) and to effectively communicate } \\
\text { its results in this domain (p. 35)" }\end{array}$ & \\
\hline
\end{tabular}




\subsubsection{Technical University of Cluj-Napoca}

As can be observed in Table 10, the concept of sustainability appears also in the strategic plan for the period 2020-2024.

Table 10. Comparison of the strategic plans of the Technical University of Cluj-Napoca.

\begin{tabular}{|c|c|c|}
\hline Word/Phrase & Strategic Plan 2016-2020 [50] (p. 9) & Strategic Plan 2020-2024 [79] \\
\hline \multirow[b]{2}{*}{ sustainability } & \multirow{2}{*}{$\begin{array}{l}\text { "chronic underfunding of higher education and } \\
\text { research in Romania, generating difficulties in } \\
\text { ensuring financial sustainability in terms of the } \\
\text { quality of the academic act (p. 10)" }\end{array}$} & Sustainability \& social inclusion (p. 6) \\
\hline & & $\begin{array}{l}\text { helping and supporting the university teaching staff to meet } \\
\text { the minimum CNADTCU criteria for obtaining the } \\
\text { habilitation degree and their subsequent promotion to } \\
\text { professors, through competition, if the financial sustainability } \\
\text { criteria are ensured by coordinating at least } 3 \text { PhD student } \\
\text { internships; (p. 21) }\end{array}$ \\
\hline sustainable & - & $\begin{array}{l}\text { The expansion, development and modernization of the } \\
\text { institutional infrastructure, as an essential element in the } \\
\text { development of efficient and sustainable academic processes, } \\
\text { which respond quickly and efficiently to the challenges } \\
\text { generated by the dynamic, competitive and constantly } \\
\text { changing inter-university environment, is a major challenge in } \\
\text { the context of underfunding of investments from the budget. } \\
\text { (p. 17) }\end{array}$ \\
\hline \multirow{4}{*}{$\begin{array}{c}\text { Sustainable } \\
\text { development }\end{array}$} & \multirow[t]{4}{*}{-} & $\begin{array}{l}\text { strengthening institutional policies, multiplying and } \\
\text { promoting examples of good practice in the sustainable and } \\
\text { inclusive development of the university in line with the "EU } \\
2020 \text { Strategy"; (p. 5) }\end{array}$ \\
\hline & & Sustainable development and inclusion (p. 16) \\
\hline & & $\begin{array}{l}\text { The strategic objective identified as part of our common } \\
\text { construction UTCN } 2024 \text { aims at strengthening institutional } \\
\text { policies, multiplying and promoting examples of good } \\
\text { practice in sustainable and inclusive development, in line } \\
\text { with the "EU } 2020 \text { Strategy". (p. 16) }\end{array}$ \\
\hline & & $\begin{array}{l}\text { conceive and develop an institutional strategy for sustainable } \\
\text { and inclusive development as an integral part of professional } \\
\text { activities and university management, by building a } \\
\text { supportive environment and community involvement and } \\
\text { awareness; (p. 16) }\end{array}$ \\
\hline
\end{tabular}

"Within this context, the Technical University of Cluj-Napoca, like many other universities in the country, is facing both major challenges and real opportunities of durable development,

durable both assuming a pragmatic, realistic approach development focused on the real needs of the regional and national socio-economic environment, by rethinking and orienting the entire educational process, scientific research and innovation towards this requirement (p. 3)"

"Supporting durable urban development (p. 27)"

The Technical University of Cluj-Napoca has a slightly shorter strategic plan [79], 22 pages compared to 30 . Throughout these pages, the concept of sustainability doubles its instances. Sustainable development is mostly focused. It appears from the beginning of the document among the eleven strategic objectives of the university, namely, strengthening institutional policies and multiplying and promoting examples of good practice in the sustainable and inclusive development of the university according to the EU 2020 Strategy. 
The plan even has a chapter dedicated to sustainable development and inclusion, in which several action directions and measurement are stated. One of them is elaborating and developing an institutional strategy for sustainable and inclusive development as an integral part of professional activities and university management by building a supportive environment, community involvement and awareness. As such, attention is paid to domains such as quality teaching, research culture, community engagement, technological capacity building, accessibility to university education and natural environment.

Sustainability appears in relation to social inclusion, the same as sustainable development. It is also linked to finance and human resources as the university aims to develop a policy to attract and motivate staff. Within this, it wants to help and support the teaching staff to meet the CNADTCU (the Romanian acronym for Consiliul Naţional de Atestare a Titlurilor, Diplomelor si Certificatelor Universitare (National Council for Attestation of Academic Degrees, Diplomas and Certificates)) criteria as long as the financial sustainability is ensured. As for the adjective sustainable, this appears only once. It is linked to the academic process within the framework of expansion, development and modernization of the institutional infrastructure.

All in all, the Technical University of Cluj-Napoca pays more attention to the concept of sustainability, linking it to various domains, such as quality teaching, research culture, technological capacity building, accessibility to university education, community engagement, natural environment and finance. Quality teaching and finance are kept from the previous plan, while the others are new.

\subsubsection{University of Agricultural Sciences and Veterinary Medicine Cluj-Napoca}

Table 11 below shows the occurrences of the concept analyzed in the plans of the University of Agricultural Sciences and Veterinary Medicine Cluj-Napoca.

Table 11. Comparison of the strategic plans of the University of Agricultural Sciences and Veterinary Medicine Cluj-Napoca.

\begin{tabular}{|c|c|c|}
\hline Word/Phrase & Strategic Plan 2016-2020 [50] (p. 9) & Strategic Plan 2020-2024 [80] \\
\hline sustainability & & Ensuring university's financial sustainability; (p. 14) \\
\hline \multirow[t]{2}{*}{ sustainable } & $\begin{array}{l}\text { "Incentivizing personal or collective initiatives } \\
\text { that can attract the financial resources needed } \\
\text { for institutional development, including } \\
\text { adequate additional salary remuneration; the } \\
\text { support of priority projects and that are } \\
\text { sustainable (p. 1)" }\end{array}$ & \multirow[t]{2}{*}{-} \\
\hline & $\begin{array}{l}\text { "While fee-based education in foreign } \\
\text { languages is perfectly financially sustainable, } \\
\text { the fees applied to many programs in } \\
\text { Romanian require a reassessment (p. 7)" }\end{array}$ & \\
\hline $\begin{array}{l}\text { sustainable } \\
\text { development }\end{array}$ & - & - \\
\hline \multirow[b]{2}{*}{$\begin{array}{c}\text { durable } \\
\text { development }\end{array}$} & \multirow[t]{2}{*}{-} & $\begin{array}{l}\text { durable development, by promoting a more efficient, greener } \\
\text { and highly competitive economy; (p. 8) }\end{array}$ \\
\hline & & $\begin{array}{l}\text { The purpose of these actions is to contribute to the } \\
\text { development of the national and global scientific heritage, to } \\
\text { the agriculture's progress as an important branch of the } \\
\text { Romanian economy and to the durable development of the } \\
\text { rural areas. (p. 8) }\end{array}$ \\
\hline
\end{tabular}

The plan for 2020-2024 of the University of Agricultural Sciences and Veterinary Medicine Cluj-Napoca is longer than the previous one [80]. Even if the number of pages has been doubled, the concept of sustainability does not appear more often, namely, three times compared to two in the previous plan. Durable development appears first in relation to the university's objectives and action directions in the field of the management of research 
activity, which are aligned to the Horizon Europe program for 2021-2027. This would be achieved by promoting a more efficient, greener and highly competitive economy. Within the same context, by carrying out research, innovation, technological transfer and other activities, the university aims to contribute to the development of the national and global scientific heritage, to the agriculture's progress as an important branch of the Romanian economy and to the durable development of the rural areas. As such, it wants to pay a significant contribution to the global and Romanian community, while taking care of the natural environment.

Finally, sustainability is also linked to finance and the university's objectives and action directions regarding the improvement of its financial capacity. In this light, ensuring the university's financial sustainability is among them.

Compared to the length of the document, the concept of sustainability is not rarely used. The link to finance has been kept from the previous plan, but the relations to community engagement and natural environment are new, emphasizing important issues for the present society.

\subsubsection{University of Bucharest}

The University of Bucharest does not employ the concept of sustainability in its new plan for 2020-2024 [81]. Therefore, no comparison could be drawn between the old plan [50], which had 11 pages and mentioned durable development and sustainability four times in relation to quality teaching, research culture and community engagement and the current one.

\subsubsection{University of Medicine and Pharmacy "Grigore T. Popa" Iași}

The instances of the concept analyzed are presented comparatively in Table 12 below.

Table 12. Comparison of the strategic plans of the University of Medicine and Pharmacy "Grigore T. Popa" Iași.

\begin{tabular}{|c|c|c|}
\hline Word/Phrase & Strategic Plan 2016-2020 [50] (p. 10) & Strategic Plan 2020-2024 [82] \\
\hline sustainability & $\begin{array}{l}\text { "For the realization of the investment portfolio, } \\
\text { the budget for income and expenses was } \\
\text { estimated in order to analyze the sustainability } \\
\text { and feasibility of the proposals (p. 75)" }\end{array}$ & $\begin{array}{l}\text { Conceiving and implementing a set of measures to develop } \\
\text { the activity of research centers, in order to achieve and exceed } \\
\text { all the sustainability indicators for research projects and for } \\
\text { the operation of IOSUD at appropriate parameters; (p. 7) }\end{array}$ \\
\hline sustainable & $\begin{array}{l}\text { "It will be a constantly developing institution, } \\
\text { oriented towards the international space and } \\
\text { financially sustainable, addressing new } \\
\text { opportunities as they arise, remaining firm and } \\
\text { consistent in its essential directions (p. 79)" }\end{array}$ & $\begin{array}{l}\text { All the investment projects mentioned above are sustainable } \\
\text { investments that contribute to achieving the desideratum } \\
\text { assumed by the University, since 2016: excellence. (p. 11) }\end{array}$ \\
\hline \multirow[t]{2}{*}{$\begin{array}{l}\text { sustainable } \\
\text { development }\end{array}$} & $\begin{array}{l}\text { "Lack of a coherent and sustainable } \\
\text { development strategy (p. 57)" }\end{array}$ & \multirow[t]{2}{*}{-} \\
\hline & $\begin{array}{l}\text { "All these fields are important for the durable } \\
\text { and sustainable development of UMF-Iasi and } \\
\text { are found in the implementation plan for the } \\
\text { operationalization of the strategic objectives } \\
\text { (p. 79)" }\end{array}$ & \\
\hline $\begin{array}{l}\text { durable } \\
\text { development }\end{array}$ & $\begin{array}{l}\text { "All these fields are important for the durable } \\
\text { and sustainable development of UMF-Iasi and } \\
\text { are found in the implementation plan for the } \\
\text { operationalization of the strategic objectives } \\
\text { (p. 79)" }\end{array}$ & - \\
\hline
\end{tabular}

The University of Medicine and Pharmacy "Grigore T. Popa" Iași has a rather shorter strategic development plan for 2020-2024 [82]. Throughout its two-column 11 pages, compared to the previous 84 , it uses the concept of sustainability twice. The first time, it appears in relation to research, which is one of the strategic objectives of the university. 
This aims to conceive and implement measures in order to develop the activity of research centers and get to achieve and exceed all the sustainability indicators for research projects and for the operation of IOSUD (the Romanian acronym for Institutia Organizatoare de Studii Universitare de Doctorat (Institution Organizing Doctoral University Studies)) at appropriate parameters. Then, towards the end of the document, various projects are presented in the framework of infrastructure development. All of them are considered sustainable investments that contribute to achieving the desideratum assumed by the University, since 2016, namely, excellence.

All in all, the University of Medicine and Pharmacy "Grigore T. Popa" Iași employs the concept considering its length. However, it is not a top priority. Compared to the previous plan, only the financial liaison is maintained. The domain of research culture is newly introduced in relation to sustainability.

\section{Discussion}

The aim of the present study has been to look at the way the most important twelve Romanian universities, classified as advanced research- and teaching-oriented universities by the Romanian Ministry of Education in 2011 [70], consider the concept of sustainability in their strategic plans for the period 2020-2024. The words sustainability and sustainable and the phrases sustainable development and durable development have been counted, interpreted in the linguistic context they appear and linked to the domains they refer to. Moreover, the perspective has been diachronic as the results have been compared to a previous study on the same issues carried on the mentioned universities' previous plans for the period 2016-2020.

The quantitative analysis has revealed a higher number of occurrences than in the past (66 compared to 43). The highest number appears in the plan of Bucharest University of Economic Studies (36\% of the total number of occurrences). This is followed by "Carol Davila" University of Medicine and Pharmacy Bucharest (13\%), which is quite far away from the first one. Closely to "Carol Davila" University of Medicine and Pharmacy Bucharest is the Technical University of Cluj-Napoca (10\%) and Politehnica University of Bucharest (9\%). All these universities, except for the last one, have entire chapters/subchapters dedicated to the concept. Bucharest University of Economic Studies even mentions the bibliographical resources in the field of sustainability consulted for the elaboration of its strategic plan.

At the other extreme, the concept does not appear at all in the University of Bucharest's plan and is encountered quite rarely in the documents of Alexandru Ioan Cuza University of Iaşi (1\%), Babes-Bolyai University (3\%) and the University of Medicine and Pharmacy "Grigore T. Popa" Iași (3\%). Compared to the previous ranking, Bucharest University of Economic Studies has raised consistently as it has used the concept of sustainability ten times more. Both Politehnica University of Timişoara (4\%) and Alexandru Ioan Cuza University of Iaşi (1\%) have used the concept fewer times than previously, namely, 21\% and $14 \%$, respectively. Babeș-Bolyai University, in turn, maintained its low interest in the concept $(3 \%)$. The most obvious changes have been encountered in the case of "Iuliu Haţieganu" University of Medicine and Pharmacy Cluj-Napoca, which has started using the concept and the University of Bucharest, which has stopped using the concept. All things considered, even if some universities pay more attention to sustainability than in the past [50], the concept is still not a top priority for most of the universities considered, a phenomenon noticed in other East European countries as well [52].

The preference for a particular word or phrase has slightly changed [50]. Durable development has become the most used (50\%), especially by Bucharest University of Economic Studies. It is followed by sustainability (30\%), which appears in all the plans [71-82], being preferred by Politehnica University of Bucharest. The two concepts do not have the same frequency as in the past when they shared the first position in the top of preferences $(33 \%)$. As for sustainable, this has been used less than previously, namely, $12 \%$ compared to $25 \%$, whereas sustainable development has kept its low percentage, i.e., $7 \%$ compared to $9 \%$ in the past. It is worth pointing out, though, that, as aforementioned, sustainable 
development and durable development are synonyms in Romanian and, as such, the preference of the language users for the constructions with the already familiar word durable as opposed to those with the neologism sustainable are a form of language protection, but also a sign that the new word has not been assimilated by the Romanian language yet. This is one more reason to urge the Romanian universities' decision takers and policy makers to use the concept of sustainability in all the official documents and all the public addresses to contribute to the Romanians' acquisition of the concept of sustainability in all its linguistic embodiments. Such conclusions are in line with the prescriptive articles [26,27] derived from the study of other national contexts and university systems that stress that, as a new concept, sustainability needs to be explicitly used as often as possible to raise the citizens ${ }^{\prime}$ awareness of the meanings associated with it and, consequently, to ensure its acquisition and to determine a social change.

As for the qualitative analysis, this has looked at the concept of sustainability in its linguistic context and interpreted the meanings associated to it from the perspective of the eight domains presented earlier, i.e., quality teaching, research culture, technological capacity building, accessibility to university education, community engagement, internationalization, natural environment and the newly proposed finance. The results indicate a strong association of the concept with community engagement since the universities have as a main direction social responsibility and inclusion, along with durable development, consolidating public policies aligned to national and international agendas, participating in partnerships between public and private organizations and institutions and training active and responsible citizens that contribute to the sustainability of the labour market. This association appears in the plans of all the universities analysed except for Alexandru Ioan Cuza University of Iași, the University of Medicine and Pharmacy "Grigore T. Popa" Iași and the University of Bucharest, which has no instance of the concept and, thus, will not appear at all in the discussion related to the qualitative analysis, dominating several of them, such as those of Bucharest University of Economic Studies, "Carol Davila" University of Medicine and Pharmacy Bucharest, "Gheorghe Asachi" Technical University of Iași, "Iuliu Hațieganu" University of Medicine and Pharmacy Cluj-Napoca, Politehnica University of Bucharest and Politehnica University of Timișoara.

The next association in frequency is finance, the domain proposed by the research team to be added to the already known ones. It usually refers to financial sustainability, funding capacity, efficient management, financial and human resources. The domain appears in almost all the plans except for those of Babes-Bolyai University and Politehnica University of Bucharest, predominating the plans of Alexandru Ioan Cuza University of Iași, "Carol Davila" University of Medicine and Pharmacy Bucharest, "Gheorghe Asachi" Technical University of Iași and "Iuliu Hațieganu" University of Medicine and Pharmacy Cluj-Napoca.

Another frequent association of the concept of sustainability is that with the domain of research culture, since the universities focused on aim to increase the number of scientific researchers, post scientific and research activities, align these activities to the 2030 European Agenda for Durable Development, or create administrative facilities and research infrastructures. The domain appears in all the plans analyzed except for those of Alexandru Ioan Cuza University of Iași, Babeș-Bolyai University, Politehnica University of Timișoara and the University of Agricultural Sciences and Veterinary Medicine Cluj-Napoca, being preferred in those of "Carol Davila" University of Medicine and Pharmacy Bucharest, "Iuliu Hațieganu" University of Medicine and Pharmacy Cluj-Napoca and the Technical University of Cluj-Napoca.

Other domains that appear in several plans, but predominate a particular one, are quality teaching ("Gheorghe Asachi" Technical University of Iași), accessibility to university education (Technical University of Cluj-Napoca) and technological capacity building (Technical University of Cluj-Napoca). The domains of natural environment and internationalization have also been found in various strategic plans but never as a preference, namely, in Babeș-Bolyai University, Bucharest University of Economic Studies, the Techni- 
cal University of Cluj-Napoca and the University of Agricultural Sciences and Veterinary Medicine Cluj-Napoca, respectively in "Carol Davila" University of Medicine and Pharmacy Bucharest and "Iuliu Hațieganu" University of Medicine and Pharmacy Cluj-Napoca.

Compared to the strategic plans for 2016-2020, several universities have kept their focus on the same domains, namely, community engagement ("Carol Davila" University of Medicine and Pharmacy Bucharest, "Gheorghe Asachi" Technical University of Iași, Politehnica University of Bucharest, Politehnica University of Timișoara, Technical University of Cluj-Napoca), quality teaching (Bucharest University of Economic Studies and "Carol Davila" University of Medicine and Pharmacy Bucharest, Technical University of Cluj-Napoca) and research culture ("Gheorghe Asachi" Technical University of Iași, Politehnica University of Bucharest, Technical University of Cluj-Napoca). To this, the research team has added the eighth domain of finance, which appeared also previously in the plans of "Gheorghe Asachi" Technical University of Iași, the Technical University of Cluj-Napoca, the University of Agricultural Sciences and Veterinary Medicine Cluj-Napoca and the University of Medicine and Pharmacy "Grigore T. Popa" Iassi. Several universities have started focusing on new domains, such as research culture ("Carol Davila" University of Medicine and Pharmacy Bucharest, "Iuliu Hațieganu" University of Medicine and Pharmacy Cluj-Napoca, University of Medicine and Pharmacy "Grigore T. Popa" Iași), technological capacity building ("Carol Davila" University of Medicine and Pharmacy Bucharest, Politehnica University of Bucharest, Technical University of Cluj-Napoca), internationalization ("Carol Davila" University of Medicine and Pharmacy Bucharest, "Iuliu Hațieganu" University of Medicine and Pharmacy Cluj-Napoca), finance ("Carol Davila" University of Medicine and Pharmacy Bucharest, "Iuliu Hațieganu" University of Medicine and Pharmacy Cluj-Napoca), community engagement ("Iuliu Hațieganu" University of Medicine and Pharmacy Cluj-Napoca, University of Agricultural Sciences and Veterinary Medicine Cluj-Napoca), natural environment (Technical University of Cluj-Napoca, University of Agricultural Sciences and Veterinary Medicine Cluj-Napoca), quality teaching ("Gheorghe Asachi" Technical University of Iași) and accessibility to university education (Technical University of Cluj-Napoca). Other universities have replaced the domains, preferring finance instead of quality teaching, community engagement and research culture (Alexandru Ioan Cuza University of Iași), community engagement and natural environment instead of finance (Babes-Bolyai University), various domains like finance, natural environment, community engagement, research culture and accessibility to university education instead of internationalization and technological capacity building (Bucharest University of Economic Studies), quality teaching instead of natural environment and technological capacity building (Politehnica University of Bucharest) or finance instead of quality teaching and technological capacity building (Politehnica University of Timișoara). Considering all these changes, Politehnica University of Bucharest has a higher interest in community engagement, while the Technical University of Cluj-Napoca in quality teaching and research culture. The University of Medicine and Pharmacy "Grigore T. Popa" Iași, instead, has a lower interest in finance than previously. Accessibility to university education has been mentioned in the present plans [71-82] compared to its total absence in the previous ones [50].

\section{Conclusions}

The present study has focused on a very important topic for today's society, namely, sustainability and its role in higher education institutions. It has particularly carried out a linguistic analysis on the use of the concept of sustainability in the top Romanian universities' strategic plans. Such an endeavor is valuable since there is a scarcity of studies conducted on the universities' strategic plans [50] and on their mission and vision statements as well as activity reports [26,31,32,34,44,50,53-55], although many scholars have advocated for the implicit or explicit inclusion of the concept of sustainability in all the official documents of the universities [26,27]. More exactly, the study has analyzed the strategic plans of twelve Romanian universities for the period 2020-2024, paying attention 
to the frequency of the words and phrases sustainability, sustainable development, durable development and sustainable and their linguistic context of appearance. The results have been interpreted and further compared to the findings of a similar previous study carried on the same universities but for 2016-2020 [50].

The quantitative analysis has shown a growth in the number of occurrences, Bucharest University of Economic Studies having the highest frequency (36\%), whereas Alexandru Ioan Cuza University of Iaşi the lowest (1\%). The comparison between periods has shown a significant growth in the case Bucharest University of Economic Studies, which is highly interested in sustainability, as indicated by other studies [63-66]. Politehnica University of Timişoara and Alexandru Ioan Cuza University of Iaşi have used the concept fewer times than previously, whereas Babeș-Bolyai University kept its low interest. The most significant changes have been encountered in the case of the University of Bucharest, which does not refer to the concept at all and "Iuliu Haţieganu" University of Medicine and Pharmacy Cluj-Napoca, which has started using the concept in the present plans. As for the preference for a particular expressing of the concept, durable development is the most used, showing a growth in preference than previously, whereas sustainable is less used. Sustainable development is the less used phrase in both corpora. However, as already mentioned, it should be considered that it is a synonym of durable development and, as such, it could be considered together. Its infrequent use may indicate a linguistic preference.

The qualitative analysis has indicated a clear preference for the association of sustainability to community engagement. Almost all the universities aim to contribute to the wellbeing of the societies in which they exist. Compared to the previous plans, the top association is the same. The second place is though replaced, finance, the newly added domain, takes the place of quality teaching. Research culture is still on third place. All the other domains considered, quality teaching, technological capacity building, internationalization and natural environment appear at least once in the corpus. This is the case also of the domain of accessibility to university education which did not appear at all in the previous plans. Politehnica University of Bucharest focusses more on community engagement and the Technical University of Cluj-Napoca on quality teaching and research culture, whereas the University of Medicine and Pharmacy "Grigore T. Popa" Iași is not as interested in finance as previously. Some changes have been noticed as several universities have enlarged their perspectives to other domains, while others have shifted their perspectives.

In addition, the conducted analysis, further longitudinal studies should be carried out in order to determine the way in which the universities act sustainably. Moreover, interviews with the universities' representatives would be useful to clarify the way the concept of sustainability is put into practice, not only employed in the official documents of the higher education institutions.

To summarize, the present analysis has shown a growth in the interest of sustainability of the universities studied. This is, however, not significant, as only few universities have doubled or tripled their use. Sustainability is still not a priority for the universities, even though most of them assume their role in creating a durable developed, socially responsible and inclusive society.

Author Contributions: Conceptualization, V.G. and S.S.; methodology, V.G., S.S. and C.E.S.; validation, S.S., C.E.S. and V.G.; formal analysis, S.S., C.E.S. and V.G.; investigation, S.S., C.E.S. and V.G.; resources, S.S., V.G. and C.E.S.; writing—original draft preparation, S.S., C.E.S. and V.G.; writing-review and editing, S.S. and C.E.S.; supervision, S.S., C.E.S. and V.G. All authors have read and agreed to the published version of the manuscript.

Funding: This research received no external funding.

Institutional Review Board Statement: Not applicable.

Informed Consent Statement: Not applicable. 
Data Availability Statement: The data presented in this study are available on request from the corresponding authors if the references [71-82] are no longer available on the websites provided in the Reference section.

Conflicts of Interest: The authors declare no conflict of interest.

\section{Appendix A}

(Source text of the English translation included in the second column of Tables 2-12) Alexandru Ioan Cuza University of Iaşi

Dintre direcţiile strategice importante ale Universităţii amintim asigurarea sustenabilităţii financiare şi securizarea juridică a patrimoniului UAIC. (p. 19)

\section{Babeș-Bolyai University}

La final, absolventul UBB trebuie să fie capabil să se integreze flexibil şi eficient în mediul academic şi/sau pe piaţa muncii, la sustenabilitatea dar şi la modificarea inovativă a cărora să poată contribui, ca un cetățean activ şi responsabil, formator de mentalitate şi de viziune la nivelul societăţii în general, nu doar al lumii economice. (p. 8)

La acest nivel, universitatea trebuie să gândească în logica dezvoltării sustenabile. (p. 20)

\section{Bucharest University of Economic Studies}

Asigurarea sustenabilității financiare a universități noastre și îmbunătăţirea capacităţii de finanțare, pentru perioada 2020-2024, se va realiza prin următoarele acțiuni: (p. 45)

Elaborarea unui Cod de Sustenabilitate în universitate și a unei broșuri „ASE pentru Dezvoltare Durabilă" care să fie distribuită electronic, prin pagina personală a membrilor comunității academice, pentru conștientizarea aplicării politicilor verzi ale ASE. (p. 55)

În acest sens, universitățile sunt chemate să se implice mai mult în procesul de dezvoltare durabilă a României prin pregătirea, în continuare, a celor mai buni specialiști pentru piața muncii, crearea și diseminarea de cunoaştere la nivelul exigenţelor unei economii globale, deosebit de complexe şi dinamice, caracterizate printr-o concurență puternică, dar și prin implicarea în identificarea problemelor cu care se confruntă economia românească, cea europeană și mondială și formularea de soluții fundamentate științific pentru rezolvarea acestora. (p. 4)

Dezvoltarea durabilă și responsabilitatea socială. (p. 10)

Promovarea unei culturi a calității, gândirii critice și inovative în rândul studenților, bazată pe responsabilitatea tuturor, în vederea asigurării unei dezvoltări durabile a economiei românești. (p. 13)

Continuarea organizării, de către ASE, a Forumului pentru Dezvoltare Durabilă și Antreprenoriat și atragerea tuturor facultăților în acest demers, cu rolul de a aduce la masa dezbaterilor cu caracter practic mediul universitar și de cercetare, cel economic privat și reprezentanții administrației publice. (p. 40)

Dezvoltarea durabilă și responsabilitatea socială. (p. 54)

Ambițioasa Agendă 2030, propusă de Națiunile Unite la finele anului 2015, reprezintă un program universal de acțiune globală în domeniul dezvoltării durabile. (p. 54)

Din multiplele Obiective de Dezvoltare Durabilă ale Națiunilor Unite, Academia de Studii Economice din București își propune să realizeze cât mai multe dintre acestea. (p. 54) 
Pentru atingerea obiectivelor care vizează dezvoltarea durabilă, pentru perioada 2020-2024, universitatea poate întreprinde următoarele acțiuni: (p. 54)

Adoptarea, la nivelul universității, a unui program de tipul „ASE pentru Dezvoltare Durabilă" (ASE-DD) pentru includerea și îmbunătățirea poziționării ASE în clasamentele internaționale de profil, precum și pentru implicarea universității noastre în mișcarea internațională de dezvoltare durabilă. (p. 54)

Publicarea pe pagina DMCI, http: / / dmci.ase.ro/, a activităților științifice și de cercetare având teme care vizează dezvoltarea durabilă. (p. 54)

Înființarea unui Birou pentru Dezvoltare Durabilă și Responsabilitate Socială care să faciliteze și să sprijine includerea politicii de dezvoltare durabilă în universitate și a studenților cu nevoi diverse de învățare în viața universitară. (p. 54)

Continuarea organizării Forumului pentru Dezvoltare Durabilă și Antreprenoriat care să vizeze și schimbul de bune practici în ceea ce privește atingerea Obiectivelor de Dezvoltare Durabilă ale Națiunilor Unite. (p. 55)

Implicarea studenților în activităti de dezvoltare durabilă, prin organizarea de workshopuri sau alte activități studențești specifice. (p. 55)

Promovarea unei politici de utilizare rațională a resurselor în vederea reducerii impactului antropic asupra mediului, inclusiv prin implementarea unui proiect de eficientizare a utilizării resurselor la nivelul întregii instituții (încurajarea dezvoltării durabile). (p. 55)

Oferirea de premii și burse pentru activitatea extracurriculară, de voluntariat a studenților, dar și pentru cea de cercetare științifică studențească, care include și teme de dezvoltare durabilă. (p. 57)

Ne propunem, pentru perioada 2020-2024, menținerea numărului de cadre didactice la aproximativ 800 de persoane și creșterea numărului de cercetători științifici, urmărind asigurarea unei structuri pe grade didactice care să contribuie la dezvoltarea durabilă a universității noastre. (p. 62)

Agenda 2030 pentru Dezvoltare Durabilă. (p. 67)

Strategia Națională pentru Dezvoltarea Durabilă a României 2030. (p. 67)

\section{"Carol Davila" University of Medicine and Pharmacy Bucharest}

Universitatea noastră trebuie să fie poziţionată, din perspectiva filosofiei instituţionale, în relaţie cu performanţa, iar din punctul de vedere al relaţiei cu competitivitatea, în spiritul principiilor sustenabilităţii şi ale dezvoltării durabile. (p. 4)

Toate acestea le voi asocia cu activităţi ce vor viza suplimentarea veniturilor Universităţii pentru asigurarea sustenabilităţii, în vederea posibilităţii de a acorda stimulente financiare bazate pe criterii calitative şi construirii unei metodologii pentru acordarea gradaţiilor de merit. (p. 14)

VIII.1. Îmbunătăţirea capacitâtii de finanţare a universitătii si asigurarea sustenabilitătii. (p. 56)

Viziunea asupra evoluției pe termen mediu și lung a Universității noastre se centrează, din punctul meu de vedere, pe o instituție puternic internaționalizată, ancorată în performanță și competitivitate, ce desfășoară un proces didactic centrat pe student şi o activitate de cercetare aliniată la Agenda Europeană 2030 pentru Dezvoltare Durabilă. (p. 4)

Prin furnizarea de dovezi științifice, UMFCD participa la fundamentarea politicilor publice centrate pe dezvoltarea durabilă și pe îmbunătățirea stării de sănătate. (p. 22) 
Digitalizarea-instrument pentru dezvoltarea durabilă. (p. 29)

VII. D I G I TALIZARE INSTRUMENT PENTRU DEZVOLTAREA DURABILĂ. (p. 54)

Identificarea de oportunități de finanțare în Programul Operațional Competitivitate și în viitorul ciclu de finanțare al UE-Agenda 2030 pentru dezvoltare durabilă, pentru soluții digitale la nivelul UMFCD. (p. 54)

\section{"Gheorghe Asachi" Technical University of Iași}

Realizarea de fluxuri de instruire, sistematizarea și certificarea acestora în vederea monetizării activităților centrului suport pentru transformare digitală pentru asigurarea sustenabilității acestuia; (p. 66)

Sistematizarea și operaționalizarea serviciilor inteligene oferite către beneficiari, dezvoltarea de strategii de exploatare pentru asigurarea sustenabilității, continuitătii și scalabilității infrastructurii; (p. 67)

Asigurarea sustenabilitatății financiare prin intermediul cheltuielilor cu regia, proporționale cu resursele utilizate-reparații, energie electrică și alte utilități. (p. 67)

desfăşurarea activităţii de cercetare ştiinţifică, dezvoltare, inovare şi transfer tehnologic, valorificarea şi diseminarea rezultatelor acestora, cu rol de componente inseparabile de procesul instructiv-formativ, pentru a contribui la progresul tehnologic, economic şi social-cultural, în sensul dezvoltării durabile şi al evoluţiei către societatea cunoaşterii. (p. 18)

\section{"Iuliu Haţieganu" University of Medicine and Pharmacy Cluj-Napoca}

Crearea la nivelul universității a unei facilități administrative de suport a activității științifice (în Departamentul Cercetare-Dezvoltare-Inovare), care să susțină activitatea de cercetare oferind servicii membrilor comunității academice, prin implicarea personalului administrativ și economic, care să permită oferirea de servicii de cercetare contribuind la sustenabilitatea centrelor de cercetare: de ex. prelucrarea statistică a datelor, consultanță privind redactarea articolelor științifice, consultanță în limba engleză medicală, informare periodică cu privire la programele de finanțare curente, propunerea și administrarea de proiecte, realizarea de articole stiinţifice de impact, analiza scientometrică. (p. 20)

Cercetarea coordonată cu viziune integratoare și de internaţionalizare, sustenabilă prin proiecte, trebuie sa fie prioritatea activităţii noastre ca universitate de cercetare avansată. (p. 13)

Contactarea mediului privat pentru a crește finanțarea cercetărilor aplicative și sustenabile din alte fonduri decât cele publice. (p. 20)

Studenții străini reprezintă o componentă principală a deschiderii universitare precum și o importantă sursă de venit pentru universitate, învățământul cu taxă fiind sustenabil financiar la programele de studiu în limbă străină, unde taxa este de 6000 Euro. (p. 40)

Cele 17 Obiective de Dezvoltare Durabilă (ODD) din Strategia națională pentru 2030 se suprapun în mare măsură creșterii capacității de atragere de fonduri pentru cercetarea în domeniile pentru sănătate. (p. 16)

\section{Politehnica University of Bucharest}

Formarea unei baze solide de aptitudini interdisciplinare, sustenabilitate și gândire antreprenorială prin programele de masterat. (p. 10)

UPB, alături de alte universități, trebuie să preia conducerea în inițiativele naționale care vizează extinderea nomenclatorului posturilor pentru personalul auxiliar cu posturi care susțin evoluțiile recente, cum ar fi administratorii 
de date (stewards) care consiliază cercetătorii în gestionarea datelor lor de cercetare (deschise), curatorii de metadate sau pentru managementul sustenabilității infrastructurilor de cercetare. (p. 17)

Asigurarea calității mediului de lucru și a sustenabilității unei comunități universitare reprezintă procupări de fiecare zi pentru funcționarea unei instituții universitare. (p. 20)

Elaborarea și realizarea unui plan de sustenabilitate pentru Campusul UPB care să urmărească tendințele de dezvoltare moderne pentru un orizont de timp cel puțin mediu. (p. 20)

Stabilirea la nivelul UPB a unei agende proactive la nivel regional, național și international pentru dezvoltarea unor proiecte sustenabile pe scară largă, pe termen mediu și lung, care dezvoltă parteneriate între organizații și instituții din mediul public și privat care va realiza legături cu agenda de cercetare și inovare a partenerilor colaboratori din mediul academic, societate și industrie. (p. 14)

Se va intensifica gradul de conștientizare pentru o comunitate UPB sustenabilă. (p. 17)

\section{Politehnica University of Timişoara}

Astfel, UPT poate contribui nu numai la dezvoltarea sa instituțională și la sporirea competitivității regiunii Vest, ci și la dezvoltarea durabilă a României și la atingerea obiectivelor de sustenabilitate stabilite de Agenda 2030 a Organizației Națiunilor Unite și asumate de Uniunea Europeană. (p. 9)

Participarea universității în parteneriate cu autoritățile locale sau regionale pentru atragerea de fonduri de la buget sau europene pentru dezvoltarea unor proiecte sustenabile de interes pentru comunitate; (p. 38)

\section{The Technical University of Cluj-Napoca}

Sustenabilitate \& incluziune social. (p. 6)

\section{The Technical University of Cluj-Napoca}

sprijinirea și susținerea cadrelor didactice din universitate în vederea îndeplinirii criteriilor minimale CNADTCU pentru obținerea abilitării și promovarea ulterioară prin concurs pe post de profesor, dacă criteriile de sustenabilitate financiară sunt asigurate prin coordonarea a minimum 3 doctoranzi în stagiu; (p. 21)

Extinderea, dezvoltarea și modernizarea infrastructurii instituționale, ca element esențial în derularea de procese academice performante și sustenabile, care să răspundă rapid și eficient la provocările generate de mediul inter-universitar dinamic, concurențial și într-o continuă transformare, reprezintă o provocare majoră în contextul subfinanțării investițiilor de la buget. (p. 17)

consolidarea politicilor instituționale, multiplicarea și promovarea exemplelor de bune practici privind dezvoltarea sustenabilă și incluzivă a universității în acord cu "Strategia UE 2020"; (p. 5)

Dezvoltare sustenabilă și incluziune. (p. 16)

Obiectivul strategic identificat ca parte a construcției noastre comune UTCN 2024 are drept principal scop consolidarea politicilor institutionale, multiplicarea și promovarea exemplelor de bune practici privind dezvoltarea sustenabilă și incluzivă, în acord cu „Strategia UE 2020”. (p. 16)

elaborarea și dezvoltarea unei strategii instituționale privind dezvoltarea sustenabilă și incluzivă ca parte integrantă a activităților profesionale și managementului universitar, prin crearea unui mediu favorizant și implicarea și conștientizarea comunitătii; (p. 16) 


\section{University of Agricultural Sciences and Veterinary Medicine Cluj-Napoca}

Asigurarea sustenabilităţii financiare a universităţii; (p. 14)

dezvoltare durabilă, prin promovarea unei economii mai eficiente, mai verzi şi înalt competitive; (p. 8)

Scopul acestor acțiuni este acela de a contribui la dezvoltarea patrimoniului ştiinţific naţional şi mondial, la progresul agriculturii ca și ramură importantă a economiei româneşti şi la dezvoltarea durabilă a spaţiului rural. (p. 8)

\section{University of Medicine and Pharmacy "Grigore T. Popa" Iași}

Elaborarea și implementarea unui set de măsuri prin care să fie dezvoltată activitatea centrelor de cercetare, în vederea atingerii și a depășirii tuturor indicatorilor de sustenabilitate ai proiectelor de cercetare și a funcționării IOSUD la parametri corespunzători; (p. 7)

Toate proiectele de investiții enunțate mai sus sunt investiții sustenabile care contribuie la atingerea dezideratului asumat de Universitate, încă din 2016: excelența. (p. 11)

\section{References}

1. De Ridder-Symoens, H.; Rüegg, W. (Eds.) A History of the University in Europe: Universities in the Middle Ages; Cambridge University Press: Cambridge, UK, 2003; Volume 1.

2. Newman, J.H. The Idea of a University; University Press: Yale, CT, USA, 1996.

3. Denman, B.D. What is a University in the 21st Century? Higher Ed. Manag. Policy 2005, 17, 9-28. [CrossRef]

4. Beynaghi, A.; Moztarzadeh, F.; Maknoon, R.; Waas, T.; Mozafari, M.; Huge, J.; Leal Filho, W. Towards an orientation of higher education in the post Rio +20 process: How is the game changing? Futures 2014, 63, 49-67. [CrossRef]

5. Kromydas, T. Rethinking higher education and its relationship with social inequalities: Past knowledge, present state and future potential. Palgr. Comm. 2017, 3, 1-12. [CrossRef]

6. University of Bologna: Our History. Available online: https://www.unibo.it/en/university/who-we-are/our-history/ourhistory (accessed on 15 July 2021).

7. Encyclopaedia Britannica: University. Available online: https://www.britannica.com/topic/university (accessed on 13 July 2021).

8. Historia: Scurt Istoric al învăţământului Superior Românesc: Cele mai Vechi Universităţi Româneşti. Available online: https://www.historia.ro/sectiune/general/articol/scurt-istoric-al-invatamantului-superior-romanesc-cele-mai-vechiuniversitati-romanesti (accessed on 16 July 2021).

9. Idrisa, F.; Hassana, Z.; Ya'acoba, A.; Gillb, S.K.; Awalc, N.A.M. The role of education in shaping youth's national identity. Proc. Soc. Behav. Sc. 2012, 59, 443-450. [CrossRef]

10. Volkwein, J.F. The Four Faces of Institutional Research. New Direct. Inst. Res. 2002, 1999, 9-19. [CrossRef]

11. Peterson, M.W. The Role of Institutional Research: From Improvement to Redesign. New Direct. Inst. Res. 2002, 1999, 83-103. [CrossRef]

12. Giesenbauer, B.; Müller-Christ, G. University 4.0: Promoting the Transformation of Higher Education Institutions toward Sustainable Development. Sustainability 2020, 12, 3371. [CrossRef]

13. Jongbloed, B.; Enders, J.; Salerno, C. Higher education and its communities: Interconnections, interdependencies and a research agenda. Higher Ed. 2008, 56, 303-324. [CrossRef]

14. McLamb, E. The Ecological Impact of the Industrial Revolution. In Eco. Available online: https://www.ecology.com/2011/09/18 /ecological-impact-industrial-revolution/ (accessed on 24 December 2019).

15. Olson, B.; Rejeski, D. The Challenge Ahead. In Environmentalism \& the Technologies of Tomorrow: Shaping the Next Industrial Revolution, 1st ed.; Olson, R., Rejeski, D., Eds.; Island Press: Washington, DC, USA, 2004; pp. 160-176.

16. Dastbaz, M. Industry 4.0 (i4.0): The Hype, the Reality, and the Challenges Ahead. In Industry 4.0 and Engineering for a Sustainable Future, 1st ed.; Dastbaz, M., Cochrane, P., Eds.; Springer: Cham, Switzerland, 2004; pp. 1-11.

17. Grigg, D. The Industrial Revolution and Land Transformation. In Land Transformation in Agriculture, Wolman, M.G., Fournier, F.G.A., Eds.; John Wiley \& Sons Ltd: Chichester, UK, 1987; pp. 79-109.

18. Schwab, K. The Fourth Industrial Revolution, 1st ed.; Business Crown: New York, NY, USA, 2017; pp. 1-9.

19. MacIntosh, R. The Background of Ecology: Theory and Concept, 5th ed.; Cambridge University Press: Cambridge, UK, 2000; pp. 1-9.

20. Dragomir, G.M.; Cernicova-Bucă, M.; Gherheș, V.; Cismariu, L. Engineering Students' Human Values as Rhizomatic Lines of Sustainability. Sustainability 2020, 12, 7417. [CrossRef]

21. United Nations Educational, Scientific and Cultural Organization. Available online: https://en.unesco.org/ (accessed on 16 June 2021). 
22. Idris, S. Preface. In Promoting Global Sustainability and Cooperation; Idris, S., Ed.; IGI Global: Hershey, PA, USA, 1986; pp. xii-xix.

23. Report of the World Commission on Environment and Development: Our Common Future. Available online: https:// sustainabledevelopment.un.org/content/documents/5987our-common-future.pdf (accessed on 1 July 2021).

24. Hussain, T.; Eskildsen, J.; Edgeman, R.; Ismail, M.; Shoukry, A.M.; Gani, S. Imperatives of Sustainable University Excellence: A Conceptual Framework. Sustainability 2019, 11, 5242. [CrossRef]

25. Petcu, D.; Gherheș, V.; Suciu, S.; Obrad, C. Corporate Social Responsibility in Higher Education. Case Study: Romanian Higher Education System. Qual. Manag. H. Educ. 2010, 1, 275-278.

26. Todoruţ, A.V.; Tselentis, V. Organizational Changes in Order to Achieve a Sustainable University. An. Univ. C-tin Brâncuşi Tg. Jiu, Seria Lit. Şt. Soc. 2012, 3, 1-12.

27. Lukman, R.; Glavic, P. What are the key elements of a sustainable university? Clean Tech. Environ. Pol. 2007, 9, 103-114. [CrossRef]

28. Dlouhá, J.; Henderson, L.; Kapitulcinova, D.; Mader, C. Sustainability-oriented higher education networks: Characteristics and achievements in the context of the UN DESD. J. Clean. Prod. 2018, 172, 4263-4276. [CrossRef]

29. Van Weenen, H. Towards a Vision of a Sustainable University. Int. J. Sust. H. Educ. 2000, 1, 20-34. [CrossRef]

30. Velazquez, L.; Munguia, N.; Platt, A.; Taddei, J. Sustainable university: What can be the matter? J. Clean. Prod. 2006, 14, 810-819. [CrossRef]

31. Denes, C.; Radu, S. Managementul Resurselor și Sustenabilitatea = Resource Management and Sustainability; Editura Universității "Lucian Blaga" din Sibiu: Sibiu, Romania, 2011. Available online: http:/ /old.uefiscdi.ro/Upload/3b4536fb-56c5-46fd-b5a5-776c8 e5f71f8.pdf (accessed on 17 January 2021).

32. Nolin, J.; Brorström, B. The University of Borås as a Sustainable University; University of Borås: Borås, Sweden, 2015.

33. Grecu, V.; Ipiña, N. The Sustainable University-A Model for the Sustainable Organization. Manag. Sust. Develop. 2014, 6, 15-24. [CrossRef]

34. Franco, I.; Saito, O.; Vaughter, P.; Whereat, J.; Kanie, N.; Takemoto, K. Higher education for sustainable development: Actioning the global goals in policy, curriculum and practice. Sust. Sci. 2019, 14, 1621-1642. [CrossRef]

35. Boks, C.; Diehl, J.C. Integration of sustainability in regular courses: Experiences in industrial design engineering. J. Clean. Prod. 2006, 14, 932-939. [CrossRef]

36. Lozano, R. Incorporation and institutionalization of SD into universities: Breaking through barriers to change. J. Clean. Prod. 2006, 14, 787-796. [CrossRef]

37. Lozano, R. Diffusion of sustainable development in universities' curricula: An empirical example from Cardiff University. J. Clean. Prod. 2010, 18, 637-644. [CrossRef]

38. Wemmenhove, R.; de Groot, W. Principles for university curriculum greening-An empirical case study from Tanzania. Int. J. Sust. H. Educ. 2001, 2, 267-283. [CrossRef]

39. Lungu, C.I.; Caraiani, C.; Dascălu, C. Educaţia pentru sustenabilitate-premisă a competitivităţii economice postcriză. Ec. teor. Şi aplic. 2013, XX, 49-68.

40. Huisingh, D.; Mebratu, D. "Educating the educators" as a strategy for enhancing education on cleaner production. J. Clean. Prod. 2000, 8, 439-442. [CrossRef]

41. Holdsworth, S.; Wyborn, C.; Bekessy, S.; Thomas, I. Professional development for education for sustainability: How advanced are Australian universities? Int. J. Sust. H. Educ. 2008, 9, 131-146. [CrossRef]

42. Deval, L.P.; Murray, T.; Bowles, I.A. Campus Sustainability Best Practices: A Resource for Colleges and Universities. Available online: https:/ / www.mass.gov / files / documents/2016/08/ot/lbe-campus-sustain-practices.pdf (accessed on 17 January 2020).

43. Sonetti, G.; Lombardi, P.; Chelleri, L. True Green and Sustainable University Campuses? Toward a Clusters Approach. Sustainability 2016, 83. [CrossRef]

44. Lozano, R. The State of Sustainability Reporting in Universities. Int. J. Sust. H. Educ. 2011, 12, 67-78. [CrossRef]

45. Weerts, D.J.; Sandmann, L.R. Building a two-way street: Challenges and opportunities for community engagement at research universities. Rev. H. Educ. 2008, 32, 73-106. [CrossRef]

46. Bender, G. Exploring conceptual models for community engagement at higher education institutions in South Africa: Conversation. Perspect. Educ. 2008, 26, 81-95.

47. Le Clus, M. Tracking and measuring engagement: A review of the literature. Australas. J. Univ. Comm. Engag. 2012, 7, 21-28.

48. Appe, S.; Barragán, D. Universities, NGOs, and civil society sustainability: Preliminary lessons from Ecuador. Develop. Pract. 2017, 27, 472-486. [CrossRef]

49. Noel, J.; Earwicker, D.P. Documenting community engagement practices and outcomes: Insights from recipients of the 2010 Carnegie community engagement classification. J. H. Educ. Outreach Engag. 2015, 19, 33-62.

50. Șimon, S.; Stoian, C.E.; Gherhes, V. The Concept of Sustainability in the Romanian Top Universities' Strategic Plans. Sustainability 2020, 12, 2757. [CrossRef]

51. Lozano, R.; Lukman, R.; Lozano, F.J.; Huisingh, D.; Lambrechts, W. Declarations for sustainability in higher education: Becoming better leaders, through addressing the university system. J. Clean. Prod. 2011, 48, 10-19. [CrossRef]

52. Dagiliūtè, R.; Genovaitė Liobikienè, G.; Audronè Minelgaitè, A. Sustainability at universities: Students' perceptions from Green and Non-Green universities. J. Clean. Prod. 2018, 181, 473-482. [CrossRef]

53. Breznik, K.; Law, K.M.Y.; Zeme, J. Mission in Higher Education in Slovenia: Sustainability in Engineering versus Others Sector. Sustainability 2021, 13, 7947. [CrossRef] 
54. Sivapalan, S.; Subramaniam, G.; Clifford, M.J. Institutional Practices Versus Student Needs and Its Implications for the Development of a Holistic Engineering Education for Sustainable Development (EESD) Framework. In Transformative Approaches to Sustainable Development at Universities: Working Across Disciplines; Leal Filho, W., Ed.; Springer: Hamburg, Germany; Manchester, UK, 2014; pp. 413-434.

55. Erdem, A.R. Üniversitenin Var Oluş Nedeni (Üniversitenin Misyonu). Pamukkale Univ. J. Ed. 2005, 17, 75-86.

56. Romania's SUSTAINABLE DEVELOPMENT Strategy 2030, Paideia, București, Romania. 2018. Available online: http:// dezvoltaredurabila.gov.ro/web/wp-content/uploads/2019/03/Romanias-Sustainable-Development-Strategy-2030.pdf (accessed on 16 August 2021).

57. Firoiu, D.; Ionescu, G.H.; Băndoi, A.; Florea, N.M.; Jianu, E. Achieving Sustainable Development Goals (SDG): Implementation of the 2030 Agenda in Romania. Sustainability 2019, 11, 2156. [CrossRef]

58. Legea Bugetului Pentru Anul 2020. Available online: https://www.edu.ro/legea-bugetului-pentru-anul-2020 (accessed on 16 August 2021).

59. Prada, E.M.; Apostu, S.A.; Gogu, E. Sustainability literacy in the Romanian Universities. Proc. Int. Conf. Appl. Stat. 2020, 1, 268-284.

60. Alexa, L.; Maier, V.; Șerban, A.; Craciunescu, R. Engineers Changing the World: Education for Sustainability in Romanian Technical Universities-An Empirical Web-Based Content Analysis. Sustainability 2020, 12, 1983. [CrossRef]

61. Popescu, M.F.; Chiripuci, B.C.; Orîndaru, A.; Constantin, M.; Scrieciu, A. Fostering Sustainable Development through Shifting Toward Rural Areas and Digitalization-The Case of Romanian Universities. Sustainability 2020, 12, 4020. [CrossRef]

62. Imbrișcă, C.I.; Toma, S.G. Social Responsibility, a Key Dimension in Developing a Sustainable Higher Education Institution: The Case of Students' Motivation. Amf. Ec. 2020, 22, 447-461. [CrossRef]

63. Badea, L.; Șerban-Oprescu, G.L.; Dedu, S.; Piroșca, G.I. The Impact of Education for Sustainable Development on Romanian Economics and Business Students' Behavior. Sustainability 2020, 12, 8169. [CrossRef]

64. Piroșcă, G.I.; Șerban-Oprescu, G.L.; Badea, L.; Dedu, S. Education for Sustainable Development-An Evaluation of Students' Perceptions within the Bucharest University of Economic Studies. Amf. Ec. 2020, 22, 346-361. [CrossRef]

65. Al Pop, N.; Todea, S.; Partenie, C.V.; Ott, C. Stakeholders' Perception Regarding Sustainable Universities. Amf. Ec. 2020, 22, 330-345. [CrossRef]

66. Dabija, D.C.; Postelnicu, C.; Dinu, V.; Mihăilă, A. Stakeholders' perception of sustainability orientation within a major Romanian University. Int. J. of Sustain. Higher Ed. 2017, 18, 533-553. [CrossRef]

67. Van Vught, F.A.; Bartelse, J.; Bohmert, D.; Burquel, N.; Divis, J.; Huisman, J.; Van der Wende, M.C. Institutional Profiles: Towards a Typology of Higher Education Institutions in Europe. Report to the European Commission. 2005. Available online: http:/ / www.utwente.nl/cheps/documenten/engreport05institutionalprofiles.pdf (accessed on 5 August 2021).

68. Legea Educatiei Nationale, nr. 1/2011. Available online: https://www.edu.ro/sites/default/files/_fi \%C8\%99iere/Minister/2017 /legislatie\%20MEN/Legea\%20nr.\%201_2011_actualizata2018.pdf (accessed on 17 December 2019).

69. Mosier, S. Does the Gown Help the Town? Examining Town-Gown Relationship Influence on Local Environmental Sustainability in the United States. Int. J. Public Admin. 2015, 38, 769-781. [CrossRef]

70. Ordinul Ministrului nr. 5.262/5.09.2011 (MONITORUL OFICIAL nr. 637/6.09.2011). Available online: http:/ / legislatie.just.ro/ Public/DetaliiDocument/131262 (accessed on 17 December 2019).

71. Alexandru Ioan Cuza University of Iași. Available online: https://www.uaic.ro/wp-content/uploads/2020/04/Programmanagerial-2020--2024.pdf (accessed on 17 June 2021).

72. Babeș-Bolyai University. Available online: https://senat.ubbcluj.ro/wp-content/uploads/2020/07/Planul-strategic-UBB-2020-2024.pdf (accessed on 17 June 2021).

73. Bucharest University of Economic Studies. Available online: https://www.ase.ro/?page=despre_ase (accessed on 17 June 2021).

74. "Carol Davila" University of Medicine and Pharmacy Bucharest. Available online: https://umfcd.ro/despre-umfcd/biroulrectorului/plan-de-management/ (accessed on 17 June 2021).

75. “Gheorghe Asachi" Technical University of Iași. Available online: https://www.tuiasi.ro/wp-content/uploads/2021/03/planstrategic-2020--2024.pdf (accessed on 17 June 2021).

76. "Iuliu Hațieganu" University of Medicine and Pharmacy Cluj-Napoca. Available online: http:/ /www.umfcluj.ro/images/fisiere/ documente_publice/Plan_strategic_2024_.pdf (accessed on 17 June 2021).

77. Politehnica University of Bucharest. Available online: https://upb.ro/wp-content/uploads/2020/03/Strategie-UPB_RUCDI.pdf (accessed on 17 June 2021).

78. Politehnica University of Timișoara. Available online: http://www.upt.ro/img/files/hs/2020/17.12.2020/HS_266_17.12.20 _APROBARE-PLAN-STRATEGIC-UPT-2021-2024.pdf (accessed on 17 June 2021).

79. Technical University of Cluj-Napoca. Available online: https://www.utcluj.ro/media/decisions/2020/10/26/Plan_Strategic_ UTCN.pdf (accessed on 17 June 2021).

80. University of Agricultural Sciences and Veterinary Medicine Cluj-Napoca. Available online: https://www.usamv.ro/images / Documentele_Universitatii/2021/PLANUL_STRATEGIC_DE_DEZVOLTARE_INSTITUTIONALA_2021_2025.pdf (accessed on 17 June 2021).

81. University of Bucharest. Available online: https://unibuc.ro/wp-content/uploads/2020/11/Strategia-de-dezvoltare-a-UB.pdf (accessed on 17 June 2021). 
82. University of Medicine and Pharmacy “Grigore, T. Popa” Iași. Available online: https://www.umfiasi.ro/ro/universitate/ conducerea-universitatii/Rector/Plan\%20strategic/PLAN\%20STRATEGIC\%202021-2024.pdf (accessed on 17 June 2021).

83. Sinclair, J. Corpus, Concordance, Collocation; Oxford University Press: Oxford, UK, 1991.

84. Tribble, C.; Jones, G. Concordances in the Classroom; Athelstan: Houston, TX, USA, 1997.

85. Baron, A.; Rayson, P.; Archer, D. Word frequency and keyword statistics in historical corpus linguistics. Angl. Int. J. Eng. St. 2009, 20, 41-67.

86. Popescu, I.-I. Word Frequency Studies; Mouton De Gruyter: Berlin, Germany, 2009.

87. Bybee, J.L.; Hopper, P.J. Frequency and the Emergence of Linguistic Structure; John Benjamins Publishing: Amsterdam, The Netherlands, 2001.

88. Baayen, R.H. Word frequency distributions. In Quantitative Linguistics: An International Handbook [Handbooks of Linguistics and Communication Science; HSK 27]; Köhler, R., Altmann, G., Piotrowski, R.G., Eds.; De Gruyter Mouton: Berlin, Germany, 2005; pp. 396-409.

89. UNESCO's 2030 Agenda. Available online: https://en.unesco.org/creativity/sites/creativity/files/247785en.pdf (accessed on 17 June 2021). 